\title{
How was a family-whānau centred music therapy approach, demonstrated within a student music therapist's clinical placement, at a rehabilitation clinic for adults with an acquired brain injury?
}

\begin{abstract}
An exegesis submitted to Victoria University of Wellington in partial fulfilment of the requirements for the degree
\end{abstract}

Master of Music Therapy

Te Koki New Zealand School of Music

Marietta van Dam 


\section{Abstract}

This project explores how the family-whānau centred music therapy approach was demonstrated, by a student music therapist on clinical placement, within a rehabilitation centre for adults with traumatic brain injuries. Parallel links between the Samoan fale tele metaphor of health and family-whānau centred approaches within music therapy perspectives - were enabled in this mahi, due to the work of Carolyn Kenny. Having developed an INDIGENOUS theory in music therapy, Carolyn Kenny emphasises the role of connectedness of each aspect and idea of sacred "space" and "place" within the music therapy session, (Kenny, (1989, 2006), Music and Life - In The Field of Play).

My own personal identity as a respectful PASIFIKA woman, and child migrant who learnt Te Reo Māori, history of Tāngata Whenua, Māoritanga, and kapa hāka on Whaiora Marāe, Otara South Auckland, 1970s - enabled the incorporation of the framework of the fale tele metaphor to represent the "personhood of the Client" and their relationships with aiga/family-whānau, medical teams/staff, community workers, as well as myself - in order to illustrate my findings. These showed that clients invariably somehow communicated and expressed a yearning for their home, had strong emotions of displacement away from home; seemed highly motivated to participate and "join in" musicking sessions due to the presence of their kin; or because they had a clear personal goal during sessions to reach a recovery stage that would facilitate their return as soon as possible to a spouse, parent, siblings, children, or to the space and place that represented "home."

Data was collected from clinical notes, assessment reviews, client reports, reflective journal. Deductive secondary analysis was used for coding from which five key themes emerged as being important in the FWCMT, and are further described in the music therapy methods, strategies and activities in a clinical vignette.

Of the eight clients, the 167 music therapy sessions which I facilitated, only 43 sessions included the physical presence of family-whānau. Findings are listed as:

(1) The spiritual, psychotherapeutic, physiological health and well-being of the client;

(2) The internal space - of the participant; 

(3) Maintaining the dignity of all - participants, family-whānau;

(4) Boundaries: The collaborative external space - visiting family-whānau, the interdisciplinary teams and staff carers who became the 'institutional family-whānau,' or extended whānau of the client;

(5) The rhythmic foundation of the client - innate musical self, external structures, influences and rhythm found in whenua and cosmos which supports the rhythmical structures of the musical, cultural self. 
Vi'ia le mamalu ma le pa'ia O Le Atua, O Le amataga, ma Le mapu o-musika-therapy; Praise Atua, Creator of the sacred healing musicking space and place to rest, replenish, and restore.

\section{Acknowledgements}

Afioga Supervisor, Associate Professor and Lecturer, Dr Sarah Hoskyns

Afioga Lecturer, \& Tautoko of Aotearoa NZ Music Therapy, Dr Daphne Rickson

Lecturer \& Tautoko of Students, Penny Warren

Clinical Placement Supervisor, Maegan VanSolkema

Music Therapy Clinical Supervisor and MiMT Fale MT Supervisor \& Mentor, Claire Molyneux Haranui Marae, Ngati Whātua - Te Awaroa Helensville, South Kaipara Kuia- Kaumātua The Participants, Clients, Family-Whānau, Kaumātua and Clinical Therapy \& Staff Teams who entrusted their wellbeing, family-whānau, time and aroha into my student music therapy practice - especially The SLT Team, The Cleaner and Chaplain who became my generous, 'clinical placement whanāu" and fellow travellers along my student music therapy travels. Tenā Koutou, Tenā Koutou, Tenā Koutou Katoa.

My Aiga-Whānau- my late parents Tupa'i Tenāsio losefo Auva'a \& Toleafoa Etevise (nee Utoaluga-Fidow), beloved Mum-in-law, art teacher, Nana Terese van Dam, Oma \& Opa, Nana \& Grandad Fouhy, Aunty Senia, Uncle Don, Great Uncle Larry, Kirsten Giles; \& to The Living especially Pops Bill van Dam \& Aiga; Aunty Sr. Telesia Utoaluga (LSOP); my beloved sisters Justine \& Rose ma Aiga; "Aunty” Terri \& Aiga; Mr Nick Roberts \& Whānau; MiMT Fale Whaea Cath, \& MiMT Fale Trustees; my St Josephs \& St Patrick's Catholic Parish; \& our Te Awaroa Helensville Community \& Ecumenical Fraternity, who awhi us all, especially my beloved Whānau with arohā and karakia throughout this music therapy journey. Surrogate Grandparents Woody \& the late Jannette Hopkins -thank you so much.

My Husband Dave, my Life - our beautiful Children, Matt \& Ruth, Alex, Therese, (d.Sam), Wickstar, Taff \& Roxy \& Mokopuna Astle \& Gio!

\section{Ethics Statement}

This project has been reviewed and approved by the New Zealand School of Music Postgraduate committee. The Victoria University of Wellington Human Ethics Committee have given generic approval for MMus Therapy students undertaking NZSM 526 Casework and Research to conduct NZSM approved studies, using secondary analysis of data, case study research or action research. Approval reference: 022131. 


\section{Contents}

Abstract

Acknowledgements.

Ethics Statement...

Contents Table

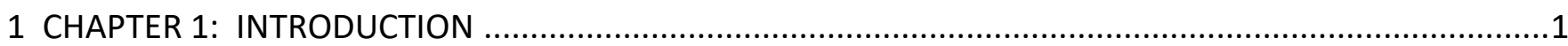

1.1 Background

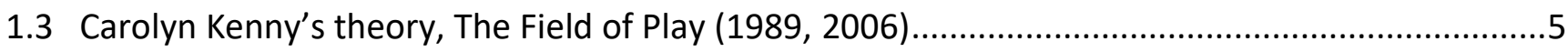

1.4 Cultural Context of the Samoan fale tele Metaphor ...................................................................

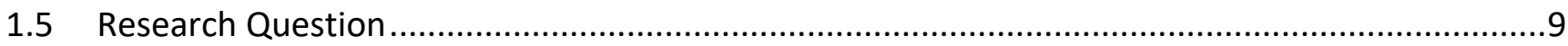

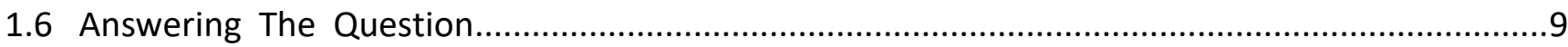

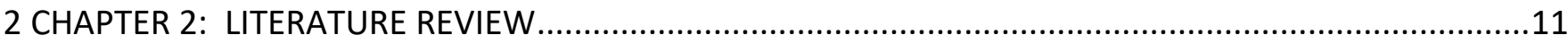

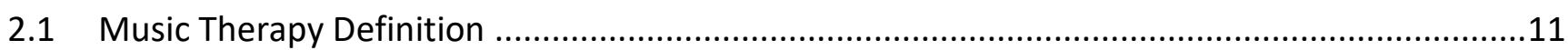

2.2 Rehabilitation and Neurological Music Therapy (NMT) ..................................................12

2.3 Family-Whānau Centred Music Therapy (FWCMT) ...............................................................13

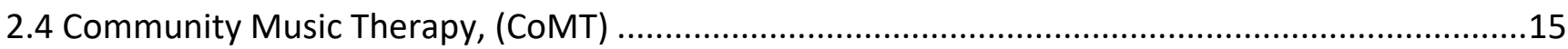

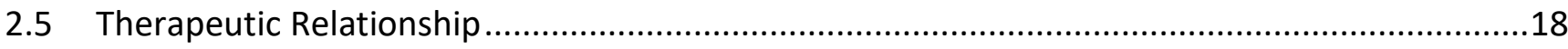

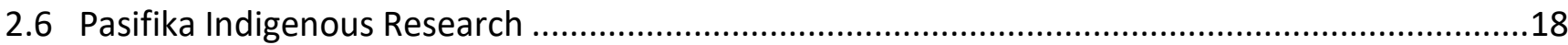

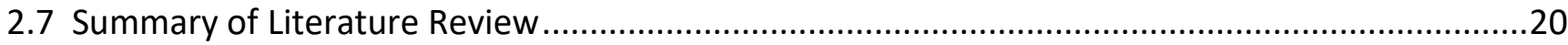

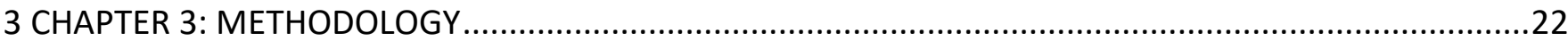

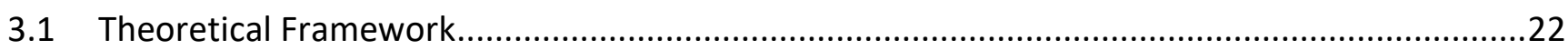

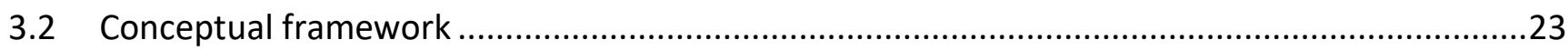

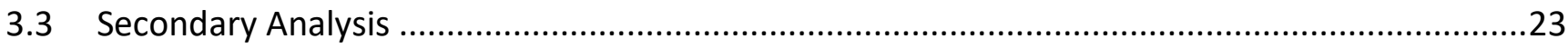

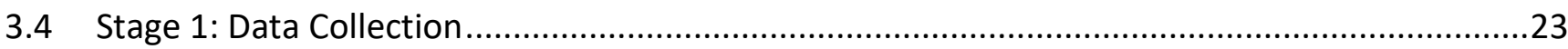

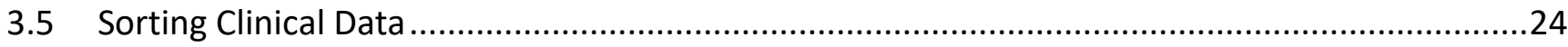

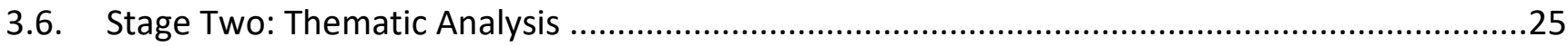

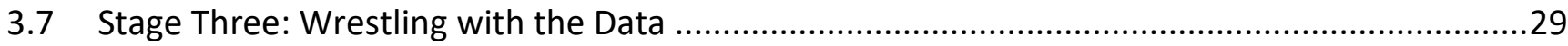


3.8 Informed Consent

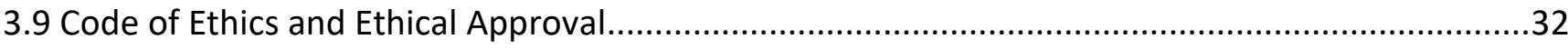

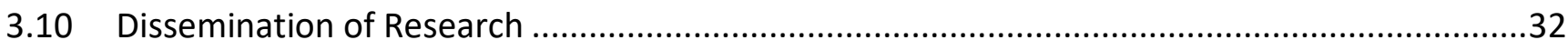

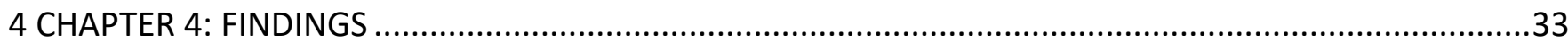

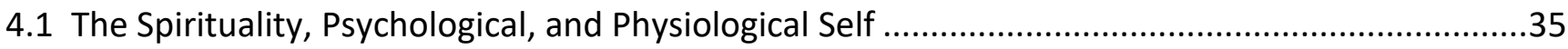

4.2 The Internal Space: Aiga Potopoto o tagata: Family-Whānau .................................................37

4.3 Boundaries - The Maintaining the Dignity of All Tangata Space ..............................................38

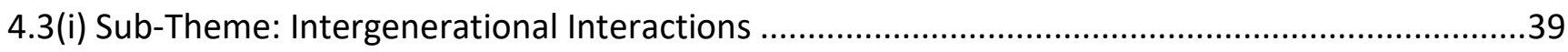

4.3(ii) Sub-Theme Howard's Teachings for an SMT - a Tribute ..................................................40

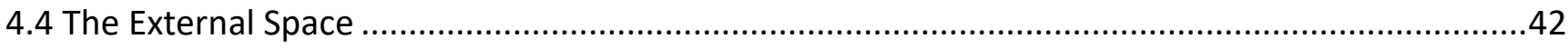

4.4(i) Collaborative challenges - The SMT's Boundaries ............................................................44

4.4(ii) FWCMT Approach With Courageous Survivor ...............................................................46

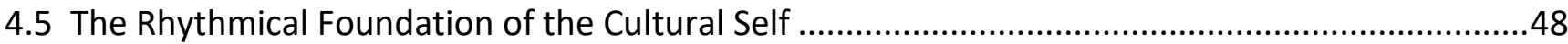

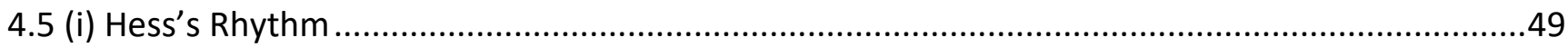

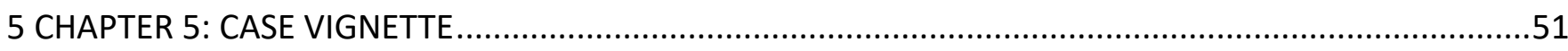

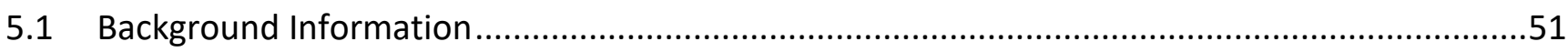

5.2 Family-Whānau In The Music Therapy 'Space' ......................................................................53

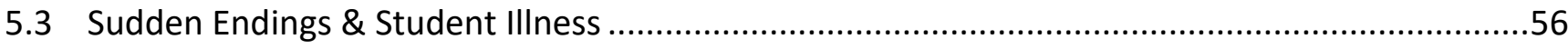

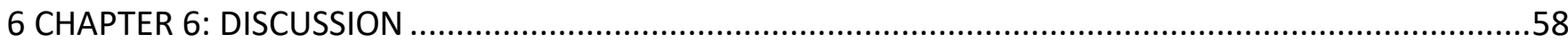

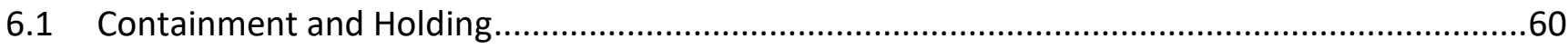

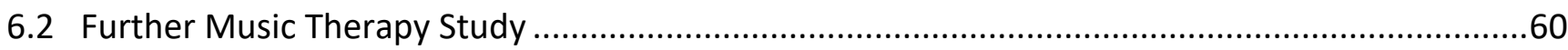

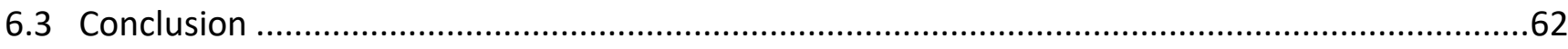

6.3 (i) Cultural Influences in Aotearoa, PASIFIKA people and MT? ...............................................62

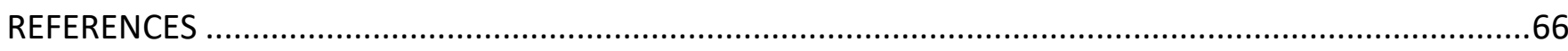

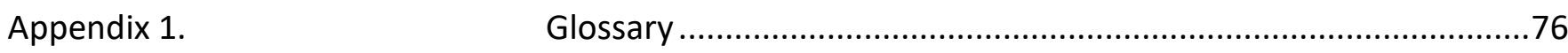

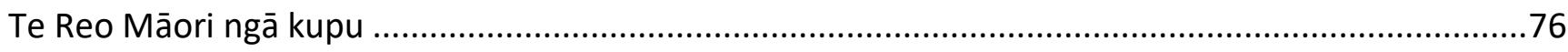

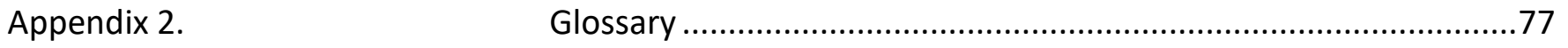




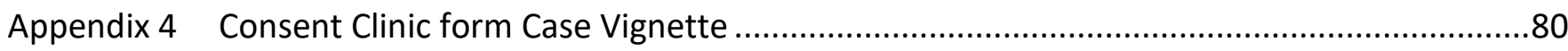

Appendix 5. Example of initial coding after colour coding step .................................................... 81

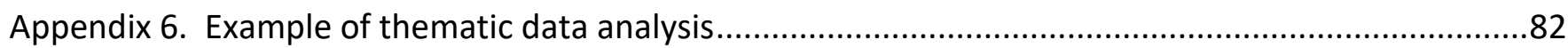

Appendix 7. Example of groupings of themes after thematic data analysis....................................83

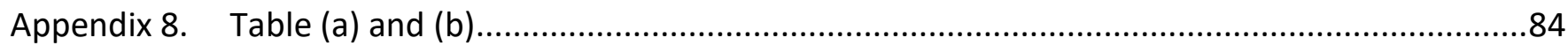

Example of Self-esteem support, in the face of domestic violence..............................................8

Example of Care staff collaborate as "Institutional Whānau" of client ...........................................8

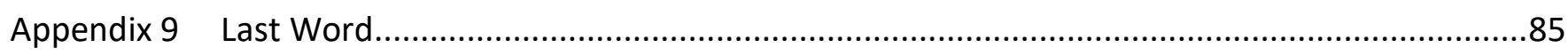




\section{CHAPTER 1: INTRODUCTION}

This qualitative research project explored my own student music therapy practice, (SMT) during and after clinical placement, in a rehabilitation clinic for adults with an acquired brain injury. Adults were addressed as 'client' and it seems tika, to do the same in this study. Secondary analysis of data was employed as it is especially suited to student researchers, being a practice-based research design, and required me to reflect about my student work as I analysed my clinical notes, client reports, supervision and reflective journal entries, (Epstein, 2010). In the course of music therapy study, I realised early on that I became engaged with the creative personcentred, humanistic approach, and have chosen to write in the first person from this perspective.

I have employed a constructivist research approach, and hereby acknowledge the influence of my own INDIGENOUS and cultural background, personal history and therapeutic assumptions which may have impacted the data, (Wheeler \& Kenny, 2005). In many ways this 'background' experience, both enabled, (as well as occasionally inhibited), during sessions where family-whānau or staff were co-creators of music with the client, in order to "observe" the session from the perspective of clients and their loved ones or staff members, (Bruscia, 2014). This helped me to gain a different perspective of the music therapy space and to observe the participants, as well as my own self from an objective, fresh 'new' angle. I relied on this ability in order to maintain a reflective student practice.

Professor Sarah Hoskyns, challenged my thinking - to go back to my birth-land's cultural roots, to listen with a new and deeper mind-set and courage of heart to the waiata and windsong of my youth in my beloved Samoa as well as in my much loved Home in the "Land of The Long White Cloud." With all of the vicissitudes, illness, grief and sense of loss over those two years and since which saw me nearly give up on this research amendment part many times - her wisdom and guidance towards the completion of this project has helped me, the struggling music therapy research student, grieving and guilt-ridden for the members of my Whānau, and closest, bestest of Friends, who passed over whilst I was 'away' studying, and so never got to practice this highly specialised and meaningful learning alongside their beloved personhood. 
Kia ora Koe Dearest Prof. Without your constant kindness, firm yet encouraging guidance, and belief in this mahi, I would have consigned this project to the place of lost dreams.

\subsection{Background}

Family-Whānau and friends were encouraged and welcomed into the facility as they are considered to be key supporters alongside the facility's mahi of client rehabilitation. Whānau become collaborative members of the rehabilitation staff team, although some were more actively involved in therapy programmes than others. Observing this led me to consider how music therapy and my student practice, might further tautoko adult clients and their family-whānau as they worked towards their personal rehabilitation goals. Or how do I employ best practice to support the interdisciplinary team's rehabilitation goals and objectives, to achieve maximum client health and wellbeing?

As I came into contact on placement with clients from diverse cultures, communities, or who were of Māori ancestry and their whānau, PASIFIKA people and their aiga, as well as Māori and PASIFIKA staff members, I became even more interested in what my student music therapy practice in support of this TBI population of adults and their family-whānau, might look like.

New Zealand has more than 36,000 TBI injuries annually, more than the number of cardiovascular disease, five times higher than stroke; and is thought to be far higher than other developed countries in Europe or North America, (Feigin, 2012). Of this population, recent research points to a rise in statistics of PASIFIKA people with acute $\mathrm{TBI}$, with falls reported in the elderly numbers of TBI cases.

Unfortunately, PASIFIKA people were more likely to discharge home without pursuing further rehabilitation, (Lagolago, et al, 2015). There was also concern that if young people have such a high incidence rate of injuries caused from assault, with a third of their injuries sustained during sport or recreational activities, what effect might TBI have on their everyday lives with family-whānau or school communities?

And begs the question - just how and exactly where were these 'assaults' taking place? The sporting fields, schools, streets or in the home? Were they accidental or something more serious? Our country is beautiful, yet we possess some of the worst 
domestic violence statistics in the world. Our PASIFIKA, and diverse communities need to continue to help each other to look towards the safeguarding of our Children and most vulnerable Ones. Sort out our own household sustainably, honestly, with courage, truth and aroha. We need to stand together, work together, travel along the "whānau-hub pathway" towards programmes or community events that bring out the best in ourselves - the opposite of the narcissistic impulse within our brain - to protect those most vulnerable in our communities and homes. To speak out against domestic violence. Because it is hard to gauge whether PASIFIKA people are reluctant to seek hospital care for suspected TBI, because of the issues of "shame" or "the tyranny of familial love" due to the aforementioned; or was it because their 'mild' TBI can be easily overlooked by medical professions, (or Loved Ones unaware of hidden abuse), when said patients are initially admitted into A \& E clinics with more noticeable, physical injuries such as sprains, fractures or broken bones from rugby matches?

I searched in vain for this in the literature, after encountering intimately again, the tragedy of TBI as a result of "assault from a spouse" on clinical placement. Perhaps, future music therapy studies will find sustainable, innovative ways for our People, PASIFIKA or not - to stop domestic violence and child abuse?

To this end, the experience of music therapy approaches as an interface between the person with the TBI, (their own complexities), and their caregivers and whānau during the initial assessment procedure, and so as a largely collaborative professional health team, may be well situated to give added support to meet this need for awareness in acute care alongside often overstretched, understaffed and exhausted hospital (DHB) teams. Would the family-whānau centred music therapy approach, be able to have an impact in strengthening the clinical experience for PASIFIKA or non-PASIFIKA peoples, and encourage them to seek ongoing music therapy, medical treatment, thus rehabilitation?

In the course of my learning on placement is the space where I first glimpsed and pondered this possibility. Certainly, my values as a person of PASIFIKA heritage have led me to agree with the literature, (Baker \& Tamplin 2006), regarding the efficacy of early music therapy intervention upon hospital admittance, as an important part of practice in TBI settings for any person (regardless of ethnicity or economic divides), who needs ongoing, long term care and rehabilitation. 


\subsection{Setting}

Prior to their admission into the facility, adults would have had to have sustained a brain injury some weeks, or months before, and were now transitioning here from hospital or clinic. Residential community care for clients who were unable to transition home, (once they had completed rehabilitation programmes), was also provided by the facility. Adhering faithfully to the principles of The Treaty of Waitangi, Aotearoa, New Zealand, the facility's philosophy and aim was to provide a client-centred, holistic approach of co-therapy and interdisciplinary consultation that encompassed all aspects of wellbeing for Tāngata Whēnua, providing many services such as a Maori practitioner of mirimiri (massage), and a Whānau-Hub, so that large groups of family-whānau, were able to visit, karakia, cook special kai, kōrero or sing waiata together. This was true for all adults and their family-whānau, which I felt to be unique to the facility - and encouraged an INDIGENOUS model of travelling along the healing pathway together with the whole clinical community, as a family-whānau. To this end they employed an interdisciplinary allied health model and I became part of this team of medical specialists, therapists, nursing and care staff assistants who were committed to rehabilitation. Family-Whānau were part of the entire rehabilitation process before admission, during rehabilitation, and in the transitioning home or towards residential care procedures.

It was the first time that a student music therapist was placed at the facility. My Clinical Supervisor, a psychology and speech therapist, warmly welcomed me into their team, and organised weekly supervision into her hectic schedule. I was rostered for two and half days a week, for five-eight, 30-60 minute individual sessions, which were mostly held at the bedside or bedroom of the clients, or in a house lounge. The warm welcome went some ways to easing my inner feelings of anxiety on being an older student, retraining; as well as one who did not come with the pre-requisite university music degree.

Referrals for MT were written on the team board from the interdisciplinary team.

Clients might be resting or asleep in their bed, sitting in a wheelchair, arm chair, or bed-chair to promote client function, circulation and socialisation. Collaborative group music therapy sessions, took place in a conference room, or lounge and very occasionally, an office or in a garden space. Sometimes they were in a physiotherapy 
session; or family-whānau, or friend(s) were there, but generally, care staff or therapy team only were present.

\subsection{Carolyn Kenny's Theory, The Field of Play $(1989,2006)$}

A life-changing moment occurred upon reading Carolyn Kenny's unique theory, The Field of Play $(1989,2006)$, which played a vital role towards the linking of music therapy theory with INDIGENOUS understanding and appreciation of music, art, and beauty. Kenny advocates that music therapists strive to honour their connection with the self and the other, and to stay close to the earth, sea and sky; highlighting the importance of deeply respecting the spaces created in the music with the participants through an intense focus on being -grew out of her 30 years practice as a music therapist... "And it is about the process of how we create the interplay between these spaces of creativity and wonder in the music therapy experience," (Kenny, 1989, 2006). The importance of Carolyn Kenny's, global research exploring the way that many INDIGENOUS societies view the relationship between music and life; of placing the arts at the centre of their lives; included the aboriginal people of Australia and across the Tasman Sea amongst Tangata Whenuā o Aotearoa, New Zealand. Kenny's influential 1980s visit described how the arts has played a role towards revitalising Māori culture, (which in turn, also influenced her work back in her homeland of North America), and Kenny's moving query to a Kuia on why there was so much art and singing in Kohangā Reo; whereby Kuia replied, "The arts provide the spiritual and aesthetic environment for the best possible development of Māori children." (p. 148)

Remarkably, Carolyn Kenny echoed the words of Catholic Scholar and Māori Priest, Doctor of Philosophy, award winning author, Pā Henāre Tate, whose work since the 1950s on the importance of whakapapa and genealogy in the lives of Māori, especially when they have moved away from the whānau system of the marae, has greatly influenced theological and ethical thought of the Church of Aotearoa, New Zealand, as well as the Justice System; his highly original and creative work in "Māori, Theology" deepening connections between the Gospel and tapu o tikanga Māori, the translation of liturgical texts into Maori, and the return of Bishop Pompallier to Motuti. Kenny left these shores saying: "I believe the elaborate Māori protocol, especially the singing which describes the ancestry and origin of the people is the 
reason their children feel safe. The singing, feasting, the social activity and the karakia - all the elements of these community events bring the people together." (p.149).

Sometimes the forgotten genealogy and family-whānau ties, may be due to geographical distances, or the emotional breakdown of relationships - were part of the dynamics that clients encountered in my placement. While healing must address the wounds of the past, at the same time it also gains momentum for creating strong pictures of possible futures, new stories gleaned from deep mythic structures, even engaging in practical future design work, (Kenny, 1989, 2006, Lupe, 2013). This dynamic relationship between future and past mediated by deep attention to the present, can create clarifying perspectives on the past; and may help create energy that moves clients towards the future with more hope and trust. In many ways we are products of multiple narratives; embedded in inter-locking family, cultural, national narratives - that we allow to define us without our realising, (Thomson \& O'Dea 2011. p10). Narrow identity fixations can create narrow fields of perceptions in relation to others and 'otherness,' and were important cross-cultural paradigms that we as music therapists need to be aware of, (Kenny, 1989, 2006, Taumoefolau, 2013).

\subsection{Cultural Context of the Samoan fale tele Metaphor}

At the core of every person is a yearning to 'belong,' (Bronfenbrenner, 1979), adding to the importance for individuals to have a sense of 'belonging,' within the wider environmental network of care, and the different challenges faced by family-whānau of cultures and varying socioeconomic groups. This seems significant alongside concepts of the fale tele metaphor, linking the individual person, their aiga/familywhānau context, and wider circles of reciprocal relationships, (i.e. village community, society, spiritual cosmos of the PASIFIKA spirituality), seem to match and mirror Bronfenbrenner's Ecological Models of Human Development - with its "reciprocal" references to relationships.

It highlights our universal connectedness in what I came to see on placement as a transformative culture of humanity, as the aforementioned divinity within all creation that interconnects us all, (again, this was reached after numerous moments of reflective thought and discussions during data mining with my supervisors, and influenced by the literature). This means music therapy's therapeutic relationship with 
clients is not just a 'reciprocal' relationship between two people, but in honour of the artiste within both client and therapist and the music within their artistic self that dances an inner song every time client and therapist meet in the music... and links them instantly to their unique cultural identity, context, and the wider community; to the true Self, and all of the facets connected with the spirituality of a person, that encompasses the Self. Perhaps this is what is so 'engaging' about music therapy, and the reasons why a client and their loved one can 'join in' despite their feelings of reluctance or shyness? For Samoans however, the reciprocal relationship between individuals and the aiga (family-whānau), is the most important role in one's life.

Being a Samoan-born person whose foundational cultural development, took place in learning the protocols surrounding the fale tele, (literally "big house"), from both my Parents in my father's ancestral lands, Falealupo, Samoa, when I was a small child; before being "ripped from the land of my birth," (as denoted by my poor parents dragging a screaming, howling, child along the Faleolo Airport tarmac and into the Air NZ Flight), to be brought up in 1970s Aotearoa, New Zealand, I acknowledge this tension. Perhaps, as it was the last memory of my Ancestral lands where I first remember meeting my Father's beloved Mother, and 13 Siblings, and many Cousins, the fale tele concept of sacred space(s), mirroring the sacredness of Tapu Tangata, is synonymous with my Falealupo Aiga, and belonging to The Ancient Ones - to Whenua; so was to become the lifelong lens through which I innately regard "the other" or "space and place."

I interpret 'reciprocal' as 'return to you in good faith and love' - or 'respectful duty,' as a member of one's family-whānau, or as part of belonging in the space that is aiga. A respectful duty completed for Loved Ones is a joy, and a blessing. For Samoans, "respectful duty" is not a chore, but the service one completes for Matua, Aiga, Nu'u, Lalolagi is a sacred duty connecting our spirit with Atua, and so we complete these "chores" with a happy and cheerful heart. For this reason and in honour of my cultural heritage learnt in this building with no walls, I humbly appropriate here the fale tele as a metaphor for the personhood of the Client and the family-whannau centred music therapy approach, (FWCMT) as a healthy 'space,' that is safe regardless of walls that are visible - or intangible to the naked eye. It is the metaphorical 
'structure' upon which I will endeavour to frame my research findings of how the FWCMT approach was demonstrated on my student music therapy placement.

It was again during our exploring together with my Supervising Lecturer, of the concept of this fale tele metaphor to encapsulate research findings, and in the subsequent discussions which included my music therapy supervisor as I now completed placement, that another significant moment happened for me. I realised that this concept of the fale tele, whare, marae, or house is not unique to INDIGENOUS cultures, but seemed more a concept of humanity, and civilization - as a universal space and place of shelter, rest and restoration for individuals and their family-whānau.

Therefore, it was a comfortable and logical process to incorporate the fale tele as a metaphor of the client's personhood, as the framework upon which to explain my research findings, and what I perceived in the data to be theirs and their whānau's experience of my SMT practice. The concept of the fale tele, as a place of ceremony, village politics, systems of justice with the court of the matai; or a space of hospitality, of rest and village celebrations was in existence pre-European, (Seuili, 2013), for centuries in Samoa. This physical and sacred concept of a space that is a designated or special place for ceremony and community gathering, (because in Samoa there is no ' $\mathrm{l}$ ' - only 'we'), translated well into what I experienced in my student practice as the principles and protocols of the MT session's 'musical space,' (Kenny, 1989, 2006).

My physical experience of the fale tele are synonymous with poetic, formal speeches, cava ceremonies, traditional music, and dance for and with manuhiri, or within the intergenerational gatherings between young and old coming together for an 'occasion.' It is the special space for the fale aitu - where the ancient court jesters of Samoa, gather villagers from near and far, for the belly aching laughs illicited by their story telling, their satirising of village, country, or international life, of politics or religious happenings. I found this exposure and ongoing training in gagana fa'aaloalo, (language of respect), or how to palu-le-ava, (make the ceremonial cava), and of Samoan protocols of 'ceremony' from my childhood was embodied within my psyche and colours the way I view the world we immigrated to - in Niusila, and beyond. 


\subsection{Research Question}

Discussions with my lecturers, further reading of music therapy literature about the role that family-whānau had in the rehabilitation of people with diverse ages and ethnographical context of the TBI population, inspired and encouraged me in the concept of this approach; because I have a natural propensity for and orientation towards family-whānau centred work. Observing the importance of the bonds between client and whānau, and those with complexities in the relationships surrounding them - deepened my natural desire to help facilitate music therapy sessions that might tautoko the family-whānau unit's health, something clearly linked to improving client wellbeing, (Oldfield, 2008). As I started my SMT practice this seemed another role that an SMT could play within the interdisciplinary team, until I began to feel a burning desire to explore what the phrase "family-whānau centred music therapy approach" (FWCMTA), really meant to me - and exactly how does this transition into the reality of clients and their family-whānau?

Hence my question was: "How was a family-whānau centred music therapy approach, demonstrated within a student music therapist's clinical placement, at a rehabilitation clinic for adults with an acquired brain injury?"

\subsection{Answering The Question}

The following literature review highlights some of the discourse that informed my SMT practice - the principles and concepts of music therapy and approaches including FWCMT of the profession. The scope of the literature and study is beyond this research, and I have chosen to focus on one facet, although I have referenced as much as I could to acknowledge the literature that had such an illuminating effect on my practice, theory, and research. Literature was sourced from Massey and Victoria Universities, library books, journals and online library data bases including Google Scholar, EPSCOhost, Scopus, using search streams such as 'music therapy,' 'whānau' 'family centred music therapy,' 'traumatic brain injury,' 'acquired brain injury,' 'TBI,' 'ABI,' 'music therapy and TBI,' or 'music therapy and rehabilitation.'

The TBI population at the facility showed that regardless of diagnosis, the importance of their "families-whānau" (hereafter "whānau"), relationships and how this related to 
their spiritual, psychological, emotional and physiological health and wellbeing, seemed crucial cross-culturally. It is hoped that findings from this study may be of interest to other students, music therapists and those who are working within the population of TBI rehabilitation clients and their whānau in Aotearoa-New Zealand.

A Glossary of words is provided in Apendices 1 and 2. As a supporter of Te Reo Māori, since being kindly embraced by Kuia Kaumātua of Whai Ora Marae, and treated as their tamariki in '70s Otara, I wanted to write the Māori language in this paper as the respected, accepted and unique taonga of Tāngata Whenua o Aotearoa, New Zealand. Thus I have chosen to restrict the use of italics mo legagana fa'a Samoa (for the Samoan language), denoting that although for Samoans born in NZ, or long immigrated to NZ - there is still a 'homeland' where we may choose to send our children to learn legagana fa'a Samoa... for the taonga of Te Reo Māori, there is no other mythical, tangible, "Hawaiiki" - this land is the INDIGENOUS home of Te Reo Māori.

Finally, I wish to sincerely thank Tāngata Whenua o Ngati Whātua of Kaipara, Kuia Kaumātua of Harinui and Rewiti Marae; Jon \& Whaea Ruth Young and Whānau, who have advised, guided and encouraged me during this project, and many previous church, community and whānau gatherings; The wonderful Te Awaroa Community Whānau \& Friends, The MiMT Fale Trustees; Kuia, Whaea Kataraina Rameka (Whaea Cath), of Te Ha Oranga \& Whānau; Jenny Davidson, John Smith, Johnny Jackson. We could not have done any of this mahi without our "Village" - Kia Ora Koutou Katoa. Fa'afetai tele lava ma Fa'amanuia Le Atua iā Outou Uma, Amene. Praise God. 


\section{CHAPTER 2: LITERATURE REVIEW}

\subsection{Music Therapy Definition}

Music therapy (MT) is an interpersonal process, where music in all of its facets physical, emotional, mental, social, aesthetic, and spiritual - can aid in improving, restoring and maintaining health, (Bruscia, 1991). Whilst these elements alone can sometimes meet client goals; in other instances it is the interpersonal relationship that develops between client and therapist, or group, that addresses client need, (Bruscia 1991:5). Twenty three years later. Bruscia noted that MT is too broad and complex to be defined or contained "by a single culture, philosophy, treatment model, clinical setting or individual definition," although the protocols of Music Therapy remain the same and comprises: assessment, treatment and evaluation, (Bruscia, 2014, p21). Music Therapy NZ, Te Roopu Puoro Whakaora o Aotearoa, defines music therapy as:

"...the planned use of music to assist with the healing and personal growth of people with identified emotional, intellectual, physical and social needs," (MThNZ 2011).

MT requires the therapist to observe/assess the person in their context of situation, culture, and whānau. This use of musical elements within the session, is designed to facilitate and promote communication, relationships, learning, movement, expression, and inner systems of organisation; to thus meet a client's non-musical goals; i.e. physical, emotional, mental, social and cognitive needs, (American Music Therapy Association, 2016; World Health Federation of Music Therapy). Using the FWCMT would have a profoundly positive and sustainable effect upon a client, within this context of a supportive, musicking whānau, whose presence is palpable within the session, whether nearby or not.

More so if we note the dramatic rise in the diagnosis of clinical depression reported that 121 million people globally were diagnosed with depression, and the evidence based research on the efficacy of $\mathrm{MT}$, has seen an increase on the number of individuals and whānau, who are turning towards MT for support, (Maratos, Gold, Wang and Crawford, 2008). Broadly categorised MT techniques are either "active" where clients co-create, improvise or compose music; or "receptive" - predominantly 
listening to music, (Maratos et al, 2008; Bruscia, 1991). Both techniques induce different types of musical stimulus upon a client's physical and emotional state.

Within a TBI setting, I did find that the combined effort of these music therapy techniques indeed helped to reduce stress, soothe pain and energised; or may enable the client and whānau, to express themselves in a "new" way leading to discovering insights into their problems through talking about the musical dialogue shared during MT sessions. It can enable a fun music-making moment, co-created by them, as the client, family and therapist meet as equal partners when all people tap into "the flow" or the "creative musical inner child" and thus aid the client's life quality, (Nordoff \& Robbins, 1977; Odell Miller, 1995, Small ,1998).

\subsection{Rehabilitation and Neurological Music Therapy (NMT)}

My clinical supervisor had met Wendy Magee in a University NMT presentation. This encouraged us both to explore this lifelong fascination with how exactly does music affect our brain, when lying in a hospital or rehabilitation clinic bed? In its most basic definition, rehabilitation applies only to illnesses and disorders that allow for actual restoration. This may present its own challenges in striving to maintain the multifaceted experience of the person, their musical process, product and context, (Bruscia, 2014); to co-create meaningful sounds - whilst still being mindful of the goal-centred, curative components that underpin 'rehabilitation.'

To this end, the question of whether music therapy is a neurological construction and by-product of neurophysiological interpretations of sound, (Thaut, 2005), revealed the efficacy of music therapy in promoting arousal and awareness for those with disorders of consciousness, (Magee \& O'Kelly, 2012). Involving family-whānau or carers in the method of Rhythmic auditory stimulation (RAS), yields sustainable benefits as client's relax and become motivated to focus on rehabilitation, easily tapping into their own auditory rhythm, and fine/gross motor control systems to address sensorimotor rehabilitation, (Thaut, 2005;McIntosh, Rice, \& Thaut, 1996; Abiru \& Thaut, 2009).

NMT seems especially important as we consider that TBI is becoming a major global health issue, and is the leading cause of injury and disability among children and young adults in Aotearoa, NZ, (NIH, 1998; Feigin \& AUT National Institute for Stroke 
and Applied Neurosciences, 2012; Lagolago, Thedom, Fairbairn-Dunlop, Ameratunga, Dowell, McPherson, Te Ao, Starkey, \& Feigin, 2015). TBI injuries can leave seemingly insurmountable changes that can have disorganising effects on family-whānau, and people's mental health, thus it makes sense to 'treat' the whānau unit (Feigin et al, 2015). Enabling whānau to co-facilitate the process of listening, playing music instruments with their loved one, (the client), can help the latter to respond to therapy and become freely engaged with the music making process where every nuance of movement or cognitive 'quickening,' (Bruscia, 2014), can positively influence physical motion, interpersonal relationships, enhancing quality of life. This is because music making does not require verbal translations yet the musical elements immediately resonate with physiological body functions, (i.e. emotions, energies, tensions), which can be supported through affect entrainment, (Nordoff and Robbins, 1977; Odell-Miller, 1995; Leman, Moelants, Varewyck, Styns, van Noorden, Martens 2013; Tamplin, Baker, 2006; Kennelly, 2006). For instance, in the live playing of music, the music therapist can speed up or slow the tempo, rhythm or dynamics of a song or piece of music whilst singing or moving together in order to support the client's motor control function and goals, and was found to be present also in the data further on.

\subsection{Family-Whānau Centred Music Therapy (FWCMT)}

Thus, if belonging to a whānau is a universal principle and way of life, as a place to raise children, and to care for older adults, therapists are surely already employing the FWCMT approach to enhance client-family-whānau care. Sometimes there are factors within or outside of the whānau putting undue strain on one or more members which may lead to the breakdown of the whole whānau way of life. There are so many variable stressors on the whānau, that any approach to its health care has to be as multi-layered, and able to be collaborative. This has come to redefine the way individuals are now holistically perceived in mainstream hospitals or private clinics, (Ayson, 2007; Oldfield, 2008; Farber, et al, 2003). The FWCMT, seems to underpin the literature given the traditional protocols of MT during assessment, evaluation, and planning which often requires consulting with a client's whānau and cultural background, or present living situation. FWCMT does therefore, require 
collaborative work with adult clients, whānau and carers; and may take place in medical, or clinics or the patient's home.

The FWCMT may help to increase whānau capacity to manage challenges within hospitals, the home environment, or as with palliative care - to improve the quality of life for people diagnosed with terminal illness in both hospice or in their home, (Hilliard, 2003; Dileo, \& Loewy, 2005). Adult carers and family members have found that MT can provide much needed support as they work through complex emotions and feelings in a way that may contain and support grief, anger and hurt; even when there is a breakdown of the whānau system, (Bruscia, 1991; Bunt and Hoskyns, 2002; Thompson, 2012; Priestley, 1989; Bright, 1986). Safeguarding the relationships of the "family unit in family centred music therapy," seems to be part and parcel of client health in the field of mental health, (Oldfield, 2008). The MT session becomes a vessel of containment and active support, offering unconditional love - a metaphor in itself of a mother, (or whānau), who loves and cares for her baby (or patient), in an enabling way so that the child grows into a healthy and well balanced adult, (healing, and quality of life post TBI injury).

This can be seen in the significance of early mother-infant interactions, and how the concept of the MT session's constructs of containment and holding, as a mother in holding, swaying, rocking, singing lullabies, crooning with her baby, providing security, (Winnicott 1965; Trevarthen, 1985).

In such a way does the MT session, holds and contains individuals and family-whānau, within the music - as they process rehabilitating from a TBI, through the creative and expressive multi modal components of music making. Neuro-disorders have a challenging effect on the whānau, and when it can result in loss of memory, physical function, speech, or give rise to sudden verbal or physical aggression, sometimes even sexual disinhibition or self-harm depending on the TBI - it is both devastating for client as well as his/her whānau, (Hitchen \& Magee, 2010; Magee \& O’Kelly, 2012). It makes sense to involve family members in MT sessions. It can also be invaluable in fostering a sense of community between the whānau or other significant people in a client's life within a clinical setting, (Dennis \& Rickson, (2012), and a recurrent theme in my research data. 
Whilst neurological music therapy, (NMT), is still an emerging field within hospitals, whānau involvement in MT for TBI during acute crisis care of the hospital setting, or nursing home is traditionally prevalent, (Hannon, Sherlock, and Thompson, 2011; Robinson, 2015). The FWCMT approach may facilitate positive client and whānau relationships within care facilities working alongside Pasfika peoples to consolidate their understanding of the importance of collaboration to complete therapy exercises, (Barret, McLellan \& McKinley's 2013); or to advocate for models that support multi-modal rehabilitation with an interdisciplinary team who assist with repetitive music therapy movement exercises that might maximise recovery time, (Hedge, 2014; Robinson, 2014).

Given that survivors typically undergo a time frame of weeks, months or even years of rehabilitation and recovery - music therapy to support the client alongside whānau of survivors seems key, as they are hugely impacted also by the TBI and invariably play a vital and ongoing role in survivors' recovery journey, (Durie, 2013; Shearer et al, 2007; Ministry of Health Qualitative Studies \& ABI Rehabilitation Family-Centric Review, 2013). Again, this is shown in the research data.

\subsection{Community Music Therapy, (CoMT)}

Music Therapists working with people in rehabilitation centres may find the ecological Community Music Therapy model as a good fit, for it asks the MT to work reflexively, being mindful of social and cultural contexts of individuals and their family-whānau, within their own community. This involves collaborative music therapy work in and for the community, helping to affect real and sustainable personal change if needed in their specific groups, (Stige, 2002). MTs work towards empowering individuals or groups to play an active role in their own therapy, healing, and recovery whilst

involving whānau in musicking together to support this process, could have a sustainable positive effect as clients transition home. I found this theory very helpful in my placement.

Whilst the music is the vehicle through which CoMT is driven, being an expertmusician is not the end-goal. Fostering a sense of belonging, community engagement, increased social justice awareness to address self-advocacy, issues of power inequalities, and cultural wellbeing - seem to be the more important components of 
CoMT, (Kenny, 1998; Rolvsjord, 2013). The FWCMTA seems indivisible and embedded within CoMT, or did it perhaps give rise to CoMT? Is it like the proverbial chicken and egg story? Be that as it may, FWCMT can delve deeper into helping raise awareness within individual whānau, when clients with acute injury and pain might feel isolated or dehumanised where medical or therapy goals take precedence. This sense of 'belonging' or 'being with' clients and family-whānau would minimise this risk, simultaneously alleviating anxiety and stress, (Baker and Tamplin, 2006). FWCMT could help calm, engage, and empower distressed clients, or groups of whānau within the same community, who feel helpless or disempowered throughout the process of hospitalisation, rehabilitation and transitioning home, given $\mathrm{MT}^{\mathrm{s}} \mathrm{s}$ tradition of facilitating meaningful shared experiences, (Bruscia, 2014).

Following adjustments to TBI - the initial response to loss experienced by the person and their whānau, often seem overwhelming and insurmountable when it results in role reversals and permanent physical impairment, (Baker and Tamplin, 2006). Furthermore, the loss of adult relationships between spouses, feelings of dependency, frustration or grief can negatively impact on the intimate relationship of a couple, (Baker \& Tamplin 2006). They note that spouses report: “...although married, they no longer feel that they have a husband or wife." (p.195).

Offering music therapy to support the mental health and emotional care of the 'hospital patient' and their whānau as they are in acute care, in beginning the treatment process, as they journey through their grief and the rehabilitation, before transitioning back home - seems urgent because the whānau goes through a parallel process to restore itself, (p.217).

Recent comprehensive work by Sidhartha Pragad, (2014), whose SMT placement was in a community music setting, in Aotearoa NZ, has helped me to further understand in depth that although the roots of community music therapy (CoMT) rest with community music (CM), thus somewhat blurring the boundaries between both, yet Pragad's research highlights that music therapists are more flexible and less directive in their facilitation of the space, and those who come to the space; focussing more on being mindful and observant of every nuance within the group's interactions, relationships, engagement, with the music therapy space, and place - with a view to 
the group's experience "empowering group members to achieve resources to achieve their group's goals." (p.19, 22)

Excitingly, Pragad's findings show us that although there are very real differences, still, there exist also outcomes which can and do overlap, such as: Music being at the central apex of both; there is a shared experience inherent, and a collaborative performative nature of the culture of a group who come together within their community to sing, dance, play music with a diverse group of people. Yet, Pragad notes that $\mathrm{CM}$ has music as the subjective end product, with a clear leader who predominantly directs and decides the focus of the group in order to reach a highly aesthetically pleasing performance goal.

However, in CoMT, the musicking between the MT and Participants is a reflexive process, where the MT is predominantly asking themselves: "Why am I doing this?" "What benefits does it have?" "Why do people attend this group?" Hence, a community music therapist is constantly looking under the surface of the musical experience. There seems to be a need to be thinking about the purpose of everything they do in relation to the purpose of the group." (p. 42)

Having come from a community music background, I found Pragad's research helpful in illustrating why I went to study music therapy. Because in the many years of individual recitals, theatre or choir group performances in hospitals and residential care facilities, we often heard from staff that "Mr L has not spoken for two weeks, and there he is singing and smiling again!" or "Oh dear, Mrs S was depressed and angry, at risk of being isolated yet is now smiling... or is now AWAKE...singing!" Over the years I came to observe how people truly were "just warming up, waking up" when we would complete our choir numbers, and suddenly be out the door to the next performance. I began to wonder what it would be like to continue AFTER Mr L and Mrs S "came awake" and to see if there was more that our music performances could help them to achieve?

In my placement, I came to see that the Community Music Therapy (CoMT), approach and style of facilitation was everything that my community musician's heart had once dreamt of. FWCMT seems inherent within CoMT; and is perhaps another layer of multi-faceted CoMT? 


\subsection{Therapeutic Relationship}

Given this, there seemed a real need for music therapy that is able to sensitively support relationships with vulnerable partners who are left grieving a family member who has been 'changed' forever, from the person they knew and loved.

For this reason music therapy traditions of the therapeutic relationship between the client, their music within, and the MT can provide opportunities for discussion, song writing, and expression of the Self, during the session, (Glassman, 1991; Gross \& Schultz 1986; Aldridge, 1997; Bunt \& Hoskyns 2002; Dileo \& Loewy,2005). Offering people and their whānau emotional and spiritual support, or facilitating communication and mental health development and caring to tautoko whānau relationships, seems key to supporting a community's health.

Music's motivating properties helps to synchronise an individual person's movement with sound, as well the dynamics of beingone of many participants in group music therapy sessions, (Silver's 2009;Huron, 2006; Merker, 2000). For example, the bond between mother and infant may rely on temporal synchrony of behaviour, (Stern, 2007; Trehub, 2003; Trevarthen, 1979); just as group cohesion also depends upon synchronisation, as may be witnessed in choirs, orchestras, families and is believed to be related to the release of hormones, such as oxytocin, which facilitates bonding and memory in the brain, (Feldman, 2007; Huron, 2006).

\subsection{Pasifika Indigenous Research}

Apparently, the fale tele, had already been shown to illustrate PASIFIKA-specific health models since the early 1980s, (Endemann, 1982). Perhaps INDIGENOUS peoples of all cultures have such a model to explain the holistic Self, (such as the Creation Myth stories for instance), which explains why I was introduced to it as a child? More recent PASIFIKA research perspectives have supported client-centred, strengths based, humanistic approaches that view the client as equally responsible in their treatment process, (Rogers, 1951), and as a way of increasing whānau-capacity to reach therapeutic outcomes, taking into consideration the individual's context as a whole, (Endemann, 1982, Seuili, 2013).

Whether this development is not purely due to the migration into Aotearoa of PASIFIKA peoples, but could be attributed to the naturally evolving ethnographical 
patterns of whānau systems which evolved from a nuclear-model to incorporate the extended whānau, a term which many Kiwis, employ to include friends who have become closely connected, (or even more so due to separation, geography or illness), than one's biological whānau.

Health professionals, often led by the Nursing providers have been incorporating more mindful assessment health programmes to maintain a culturally sensitive and balanced focus on measurable outcomes, (Saggers et al., 2011; Isaacs, Pyett, OakleyBrowne, Gruis, \& WaplesCrowe, 2010); with the humanist view of a client's dynamic energy that can transcend and transform illness, (Kenny, 1998, 2014). Simultaneously, in Aotearoa, NZ, health focused approaches seeking to interweave PASIFIKA concepts into general health systems, (Endemann Pulotu, 1982), conceptualised a Fale-fono Model.

Such works have helped to incorporate the fale tele metaphor, to encapsulate the relationship between the client and their music explored in FWCMT. If every client can be encountered as an aesthetic being, a beautiful work of art, a dynamic entity and space, and more - the therapist is also viewed thus as they commit to the creative space within, and that which surrounds the client, (Kenny, 1989, 2006), there is always a meaningful encounter.

Therefore, the FWCMT approach is from a tradition of knowledge that seems to reverberate into the $21^{\text {st }}$ century, that for the individual client, it is about relationship with the therapist yes, but even more; it's the presence and voice of their spouse, parent or child - that seems to be the most healing, sacred sound in the universe! How privileged is the MT who can facilitate this for the client and their loved ones? Because these therapeutic relationships provide the safe space for the familiar sounds and tones of MT, to become the springboard empowering the client to "fly free" into a new space of power:

"... a field of play with new rules, no rules, an open field of surprises and possibilities of new discoveries the musical questions that speak our inner yet-to-be-knowns. We are playing the field of music, and the field of music is playing us - a child who never played, a father who grieves for loss, an older woman who thought she could no longer remember but can." (Kenny, p.459) 


\subsection{Summary of Literature Review}

Defining or documenting the rich cache of theoretical literature and the many different music therapy techniques, theory or diversity of music therapy approaches is a very difficult process, (Bruscia, 2014), and beyond the scope of this study, but the aforementioned have been reviewed to contextualise my student music therapy practice. Of note is the continued trend over the past ten years of the FWCMT approach in the literature.

Contributing greatly to the discourse of INDIGENOUS models of health, especially is The Field of Play, (Kenny, 1989, 2006), and music therapy New Zealand research literature such as Opening Doors, (Brooks and O'Rourke, 2002) - which is the theoretical link to the fale tele metaphor encapsulating the healing spaces of music therapy, co-created with client, whānau, and staff. "Space is crucial - the type of space that music therapists create, and the "condition of this space," (p.123), is key for patient, client, participant. Music Therapy Aotearoa NZ Pioneers and their supporters, the Professional Body of Te Koki School of Music, Massey University \& Victoria University NZMTh and their many students, are the shoulders whom we stand upon, to continue to learn and grow today. I feel humbled, and very privileged to be a tiny part of the Aotearoa $21^{\text {st }}$ century leg of the voyage.

It brings me full circle and makes sense of my formative years as a child in Samoa, and then Aotearoa, (perhaps I was present at a 1970s MT presentation without realising)? Certainly this is the country in recent years where I have been privileged to experience the 'unspoken body-language' as a wordless dance, (language, gestures, gaze, voice, body, expression, spirit, space), that is negotiating status and authority, whilst formal speech is taking place, (Alessandro, 1992). However, this 'musical dance' is not just to be reserved for ceremony - because it can only produce meaning inside of a cultural space and composed of complex layers, so - is never a 'neutral' space.

Perhaps then, the challenge for the FWCMT approach, is that for many people, whether Māori, Oceania, Arabic, European, Asian or African, this level of engagement in the therapeutic process, and the involvement of the aiga, may leave many familywhānau feeling vulnerable and exposed, (Seuili, 2013). It challenges the therapist to 
know herself, their reason for seeking to engage with people who are in extremely vulnerable states of being; and to be unconditional in her aroha within the sacred musical space, within the music therapy session - within the community. Health Professionals, individuals, or Parents, family-whānau, seeking music therapy for a loved one, must always feel safe to join in the musicking experience or unjudged as a parent, spouse, sibling - feeling awhi, embraced in the musical space and accepted in aroha, (Ansdell \& Meehan 2010, Molyneux, supervision notes 2015). 


\section{CHAPTER 3: METHODOLOGY}

\subsection{Theoretical Framework}

The theoretical framework of this research began from a constructivist epistemology, which relies on myself, (researcher), to be a conscious subjective participant situated within the research, rather than being a passive observer, (Schwandt, 2001:192). Secondary analysis was employed as a methodology to read through clinical placement notes which I had written as a student music therapist, and was stored on a facility database. My reflective journal, supervision notes and client reports or reviews were also included as 'clinical data.' As I am reflecting back into my own practice to deepen my own understanding of my student MT work entirely through close examination of data, there are no research participants.

Every effort was made to respect the clinical data sourced from genuine interactions during music therapy sessions in the context of my placement facility, as well as being mindful of the relationship between the data and myself, (Wheeler \& Kenny, 2005).

Acknowledging that my own personal history and viewpoints, social and cultural context and ideas have also been utilised, alongside the clinical data, to guide and give meaning to the research, and to encapsulate 'research findings' in the fale tele metaphor, seems important. As both student practitioner and researcher, I needed to be aware that objects and subjects of inquiry can overlap and mutually affect one another, making it difficult or even impossible to distinguish and interpret the meanings which others whom I encountered through my MT placement, have about their world, (Creswell, 2007). Personal reflexivity, using a reflective journal as selfobservation and self-inquiry, as well as my supervision experiences and notes, (Bruscia, 2014, p.54), were crucial in safeguarding the data to ensure it could be viewed objectively, to minimise 'contaminating' the data with personal bias and preconceptions, or impulses to 'prove' efficacy or existence of family-whānau centred music therapy concepts. Therefore, this study was a practice-based research, requiring the process of 'clinical data mining' which generates evidence or findings from the data pertaining to my research question, (Epstein, (2001); (2012); O'Callaghan \& Barry, (2009)). It meant reading and coding data without preconceptions of what I should or shouldn't find, and carefully examining the 
thematic grouping of codes in order to re-visit data several times, for new interpretations on pre-existing knowledge, (Guba \& Lincoln, 1994).

\subsection{Conceptual framework}

As musical beings with an ever-changing energy, and the dynamics of animated selves in the world, the cosmos; music therapy provides a structure that holds and reassures, or alters consciousness through repetition of melody or rhythm, and sets in motion the plasticity of the brain, carrying "all participants into an unknown space," (Kenny, 1989, p.459). As aforementioned in this exegesis, I have appropriated the Samoan fale tele as the metaphorical framework to conceptualise my findings.

\subsection{Secondary Analysis}

I utilised qualitative secondary analysis of data, meaning the methodology of using pre-existing data for research, (my clinical notes and reflective journal), to explore and answer my research question, or to generate others that are illuminated throughout the process, (Heaton, 2004). It is a very helpful way for student researchers to learn about research methods - using the tools (interviews, transcriptions, patterns of findings), to relate to their research learning. I reviewed my clinical notes and journal reflections, client reports and reviews as well as supervision notes from my placement, to look for answers. Clinical notes from nine clients were selected for data analysis, five female and 4 male. The notes included were those belonging to clients whose whānau had been in the session, or who had spoken with me regarding their loved one. Four of the clients were Māori, hence it is tika that I consult Kuia, Kaumātua about my SMT practice, and ask their karakia and advice - and karakia for the facility, and other clients who were from the UK, Oceania, and Asia.

\subsection{Stage 1: Data Collection}

Prior to data collection of clinical notes from the facility's database, I included a letter requesting permission when submitting my research proposal. Only when this was granted, did I feel it ethical for me to select clinical notes pertaining to the clients whom I had assessed, planned and tailored music therapy sessions for. Sessions with clients were booked via this database and were signed off on a daily basis. This 
ensured an efficient and accurate process of collating data, storage, and monitoring the rehabilitative progress of clients. I was granted permission to print clinical notes which I did on my last week of placement. They ranged from the period from March to September 2015. I also kept a journal reflection pertaining to the music therapy sessions. MT practice was completed with both client and whānau which meant that there were clinical notes that may have demonstrated this that I chose to omit.

\subsection{Sorting Clinical Data}

As some of the clients had already discharged home, or to other facilities, their data was no longer accessible. I sought the assistance of my clinical supervisor who kindly obtained clinical notes, then familiarised myself with this data. I gave numerical order to the data, by numbering them before typing up all clients' data onto Microsoft Works tables. When this was completed, I was able to read through the tables and look for anything that I may have omitted. Below is an example of how this was done, with the data revealing the presence of FWCMT when facilitating MT sessions with clients/whānau and their interpersonal relationships, (please see Appendix 5). It is worth noting that the client's spouse had surprised the SMT by organising for their daughter and grandson to come to the facility and join in with her mother's MT session. But it was only possible due to the family being present in a prior MT session, as well as the therapeutic relationship that we had built together.

\begin{tabular}{|c|c|c|c|c|}
\hline Date & Text & Label & Code & Comment \\
\hline $06 / 05 / 15$ & $\begin{array}{l}\# 164 \text { Mrs L } \\
\text { (Brenda) engages } \\
\text { well when her } \\
\text { Whānau are } \\
\text { surrounding her. } \\
\text { Daughter \& her } \\
\text { little son and } \\
\text { husband playing } \\
\text { instruments. } \\
\text { Brenda requested } \\
\text { "Somewhere Over } \\
\text { the Rainbow"... } \\
\text { and sung this ... } \\
\text { Plan to continue } \\
\text { with MT in group \& } \\
\text { family. }\end{array}$ & $\begin{array}{l}\text { Client } \\
\text { connects } \\
\& \\
\text { engages } \\
\text { in music } \\
\text { with her } \\
\text { family. }\end{array}$ & $\begin{array}{l}\text { Family } \\
\text { in } \\
\text { session } \\
\text { Breakth } \\
\text { rough }\end{array}$ & $\begin{array}{l}\text { Surrounded } \\
\text { by her } \\
\text { husband, } \\
\text { daughter } \\
\text { and } \\
\text { grandson, } \\
\text { the client is } \\
\text { relaxed, } \\
\text { content \& } \\
\text { engaged } \\
\text { with her } \\
\text { musical } \\
\text { self, } \\
\text { (requesting } \\
\text { song, \& } \\
\text { singing). }\end{array}$ \\
\hline
\end{tabular}

Figure 1: Initial data analysis 


\subsection{Stage Two: Thematic Analysis}

The data collected from my clinical notes and reflection journals, during placement was divided into those that were related to the research question, and the data which had little or no relevance to the study. These were colour coded initially, before recoding, (please see Appendix 6). I was then able to use the data analysis process, using thematic analysis based on Braun \& Clarke's (2006) defining argument on the validity of qualitative research - "as a method for identifying, analysing and reporting patterns," (themes), within data.

Themes were crucial as they helped me to derive information from the data that seemed related to my research question. It gave meaning, or a patterned response from the data, allowing me to try and sort/decide on the themes that were recurring in the data. Although overwhelming at times, thematic analysis also allowed me the space to travel backwards and forwards throughout whole sets of data to re-examine the data for themes I may have overlooked. Braun \& Clarke (2006), note the six stages of thematic data analysis that must be adhered to in order to produce research that can contribute to society.

I resorted to organising the data onto computer tables, colour coding and then mind mapping/setting out onto paper what looked like possible themes, as I continued revisit the data. This was a more familiar medium for me to work with than putting data entry onto Excel 2013 computer forms, which was not a personal strength.

I varied from writing out the emerging themes on large sheets of paper, exercise books to making similar lists of what seemed to be emerging themes on the computer. As I reflect back on this experience, it would have been less 'messy,' and less confusing and overwhelming, if I had logged all of my "data entries" onto a computer excel sheet, or Microsoft word tables as suggested in class. One needs to do an in depth class on how to use databases, search engines and computer excel software in order to lessen the confusing stress of data mining.

Below is an example of data I transcribed from an exercise book. The first column related to the data text, which I was reading from as I made notations, (data source "Mrs L" and "Hess's"clinical notes). 


\begin{tabular}{|c|c|c|c|}
\hline What is happening? & & Label & Code \\
\hline $\begin{array}{l}\# 31 \text { Musical Connection between } \\
\text { *Mrs L and spouse drumming, and } \\
\text { then singing together. After this, } \\
\text { Spouse shared emotionally that this } \\
\text { is the first time in seven months that } \\
\text { he has "felt like a husband rather } \\
\text { than just her carer." He said he was } \\
\text { "grateful to have his wife back." }\end{array}$ & $\begin{array}{c}\text { Client AND Spouse } \\
\text { share meaningful } \\
\text { moment }\end{array}$ & $\begin{array}{l}\text { Belonging Rediscovery? } \\
\text { Connection } \\
\text {-Husband became } \\
\text { enthused and } \\
\text { renewed efforts to } \\
\text { encourage } \\
\text { ent in her } \\
\text { physiotherapy...wh } \\
\text { ich was her next } \\
\text { session }\end{array}$ & $\begin{array}{l}\text { Motivational } \\
\text { Hope } \\
\text { Reduction in stress and anxiety for } \\
\text { both client and her } \\
\text { husband } \\
\text { Support Relationship }\end{array}$ \\
\hline $\begin{array}{l}\# 30 \text { *Hess is considered in PTA, } \\
\text { with global aphasia. Yesterday he } \\
\text { did not remember any Māori } \\
\text { waiata. Today, during MT he } \\
\text { reached for maracas... and at end } \\
\text { then remembered all of the waiata } \\
\text { “E Hara I Te Mea," "Hoki Mai" \& } \\
\text { "Pokarekare Ana” which he had } \\
\text { been unable to recall in the past } \\
\text { three sessions. Music connection } \\
\text { with his cultural identity. } \\
\text { He also asked to pray a karakia } \\
\text { during group MT, and did so in } \\
\text { Te Reo! }\end{array}$ & $\begin{array}{l}\text { Cultural music in } \\
\text { session } \\
\text { Client engages with his cultural } \\
\text { music within } \\
\text { Cultural identity } \\
\text { invokes karakia } \\
\text { ritual? }\end{array}$ & $\begin{array}{l}\text { Cultural/Belonging } \\
\text { (Connection with } \\
\text { cultural identity, } \\
\text { cognitive } \\
\text { ability)Motivation } \\
\text { to } \\
\text { musicking, led to increased sense } \\
\text { of enjoyment, smiles, laughter \& } \\
\text { music instrument playing. }\end{array}$ & $\begin{array}{l}\text { Reminiscence, Cognitive support } \\
\text { pnger sense of } \\
\text { Identity/Self Karakia } \\
\text { in Te Reo }\end{array}$ \\
\hline
\end{tabular}

Figure. 2 Example of two different clients' secondary analysis of data: CULTURAL IDENTITY

An example of other codes which were logged were "promoting agency, grief, sense of loss, importance of humour, challenges, difficulties, a sense of belonging, familywhānau feeling a sense of hope, love/aroha/alofa". For Mrs L and her husband, it seemed that the FWCMT approach provided a musical space enabling her shared history and musical culture, to 'come out and play' or to be 'seen and heard.' It was their love for each other, their musical history which was supported within the "therapeutic relationship," of the MT session “space," (Kenny, 1989, 2006). What seems important at the time is how the session facilitated meaningful music making opportunities for this couple, and their whānau, and provided a layer of rich, cultural and professional musical context for Mrs L, which was previously unknown to the facility, interdisciplinary team and care staff.

This data analysis uncovered ways that the client and family-whānau surprised us, which gave the client and whānau a sense of pleasure and pride, in turn giving the facility's therapy team an opportunity to discover the multifaceted client. It enabled a client to call upon her own strength and reserves, to self-soothe' - a technique which the therapy team were trying to help the client develop. This ability, and her playing of the music instruments demonstrated the client's organizational ability unique to the musical space, and so enabled her own enjoyment in being able to share a fun 
and meaningful experience with her husband, (Kenny, 1989, p.203). It also gave her husband hope.

- As it had been Mrs L's husband who 'planned' this music-sharing, asking me the day before if he could bring a music instrument, it also gave both wife and husband a sense of agency, of being heard, listened to and then given 'control' and so, empowerment. Most of all - hope - that in their musicking, he was again able to enjoy a shared musical experience with his much loved wife, something he shared, had not been possible since her TBI.

Perhaps Mrs L had the most surprising "cultural identity" revelation in the data for me. Finding out how vulnerable a client can be as a 'Palagi' woman, with little support around her except from her small whānau with only one child, and no extended whānau or community around them due to being recent immigrants, was a steep learning curve.

- Similar themes regarding the importance of "cultural identity" and "whānau in session" in the music therapy space, were found to be prevalent in all $167 \mathrm{MT}$ sessions of client data sourced for this study. Unfortunately, the appearance of what looked like 'dyadic' themes became a distraction for me and I became fixated on this theme.

This became a flaw in the research and depressingly cost valuable time. Yet in retrospection, this maddening experience did increase my own awareness of having to be alert to "distractions," and to ponder why I became so frustratingly 'fixated' on this theme. It dawned on me that the recent passing of Loved Ones whilst I was away studying, my father six months prior to embarking on my masters paper, and soon after the death of his sister, (who was like a second-mum to me); is probably why I formed an 'emotional attachment' to this data. It highlighted to me, the importance of music therapy supervision on a personal/professional level, and helped me to gain insight into some of the patterns embodied within the FWCMT, to be mindful of when working with individuals or whānau. 
The following illustration, shows the emerging sub-themes, one of them being the aforementioned "dyads" during the sorting the codes into categories, with sub themes, as suggested by (Braun and Clarke, 2006).

I found seven key themes with sub themes which stood out with the whānau being in the session. I then chose one of the below sub-themes to re-examine and to search for in the data (fig.2). Once I examined these I circled them - (shown as underscored below), the codes which co-related with the data: connection empowerment - Belonging - motivating - improvisation - song writing - lyrical analysis - singing - dialogue - talking, discussion.

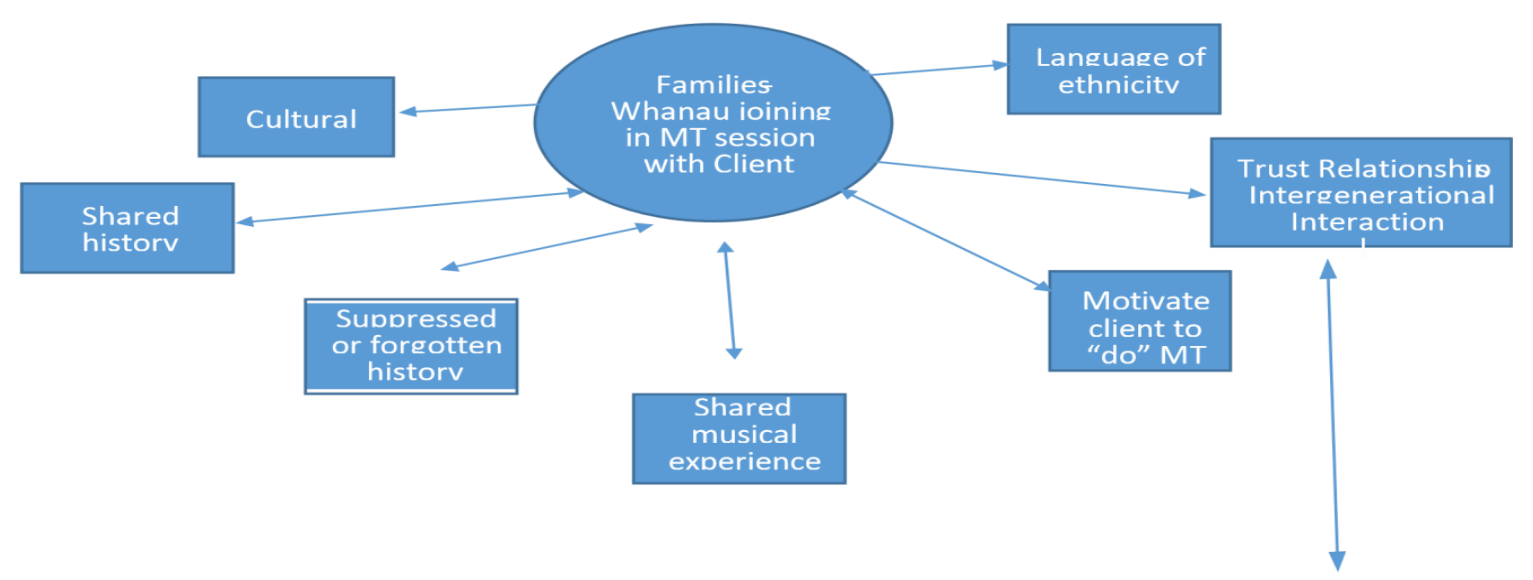

- Attunement

- $\quad$ Connection-Empowerment

- Agency

- Belonging $^{\text {? }}$ Strength

- Motivating

- Balance mind-body

- Normalising

- Comfort

- Improvisation/song writing/lyrical analysis/singing-Dialogue, talking, discussion

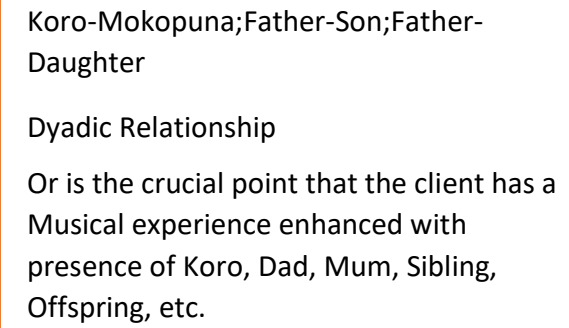

Figure 3. Example of mind-mapping themes 


\subsection{Stage Three: Wrestling with the Data}

However in doing so, it seemed difficult to choose between themes and important techniques to either explore further or to discard. The process seemed very convoluted, messy and confusing. Thus they had to be reviewed and refined in order to try and concisely present the meanings represented in the data, and finally definite patterns became defined for me:

- A picture began to be revealed what might be links between what was taking place in the music therapy space, and why a client seemed to feel comfortably confident to play the tambourine (by tapping it with two fingers. Was it due to their whānau's active presence and encouragement? Their sibling, mother, father or koro (grandfather), was also 'playing the drum:'

The following paragraphs illustrate how a group of codes were categorised. For example, from my perspective, this led to the emergence of the theme of "a therapeutic space," (Kenny, 1989, 2006): (Please see Appendix 7).

The 'therapeutic space,' seems an 'enabling' component in the relationships between the client and whānau, staff or myself and took place in the music-making space. It was also highlighted as a 'space' that was unique to music therapy, as noted in comments from clients and staff in the data, about MT being "so different," "relaxing and enjoyable, unlike other therapies," "this is the first time I've played an instrument"... This seemed to lead to the recurrent themes below:

1. Attachment: A person's connection to their music, or attachment to whānau, care staff, therapy team. Therapeutic relationships.

2. Strength, Sense of Self/Identity - from remembering shared history with their whānau.

3. Empowerment \& Self Esteem: feelings visible or expressed regarding cognitive and physical ability, e.g. during interactive musicking.

4. Cultural connection - Identity of Self, of family history, of cultural music

5. Spiritual/Belonging, inclusion, comfort - to whānau, church community, group.

6. Motivation - to commit to the music space, to interpersonal relationships, or to therapy goals of family-whānau and the rehabilitation facility. 
Upon reviewing the data it seemed that the 'cultural identity' of each client did have relevance in their music choice, (for client, whānau as well as staff, and for myself as SMT) - and played a part in music instrument choice. For example, the data showed that the majority of PASIFIKA clients or whānau and staff seemed to gravitate towards the guitar, djembe, darbuka, congas or bongo drums; with certain staff members so proficient that they played polyphonic rhythms full of texture which enhanced the music-making experience for all MT participants.

As this then was recurrent, I further explored the theme of "Cultural Identity" and in the data was found a further division of sub themes: - i.e. From 'Cultural Identity' emerged, (as people identified themselves and the music they enjoyed); 'cultural boundaries' within and surrounding the cultural identity and space of the client; the 'cultural and spiritual self,' (as participants asked for prayer from the chaplain or group even when they were referred to as "not affiliated to any religion;" or were noted in the data as leading karakia); the 'historical self,' (their context); the 'psychological self' (their rehabilitation needs leading to referral for MT); and the physiological self,' (collaboration with the physiotherapy or nursing team referrals).

What seemed to be revealed is that clients, whānau or carers appreciated karakia, during sessions, (also requested whenever the facility's chaplain was present), for themselves or for someone in their family. Spirituality then seemed important as it transcended ethnographical, political, gender, age or TBI boundaries. It was a very important part of the clients who identified themselves as Māori or PASIFIKA. But whilst exploring this I also found that karakia was just as 'important' for clients who were palagi, or of Asian heritage, as well as staff from other countries.

Finally, a 'new' space emerged for me as a direct result of wrestling with my data which was only revealed whilst painting the fale tele illustration for this paper. I had 'situated' music therapy within the "collaborative space." It had been my experience on student placement that often music therapy seemed like the 'bridge' or 'link' interconnecting the healing 'spaces,' between the client and I, or with family-whānau and client, care staff and therapy teams. For me, it was as if music therapy was a metaphorical 'hongi,' (or the healing space in-between where breath mingles and become 'one'); or the metaphorical 'ifoga,' (a Samoan forgiveness ritual which takes 
place on the entranceway of the fale tele) - seeking to restore the interpersonal and community relationship.

But as I brushed paint strokes over the picture, (figure 4. below), the paint became in my mind - like a healing piece of music 'going everywhere' and 'transcending spatial boundaries of the physical as well as temporal' - just like the musicking experience I had uncovered in the data. That is, music transcends cultural, gender, age, religious, political or economic divides. Instead the musicking experience is transformative because it engages a client's wairua, or psychological and emotional as well as their physiological Self.

\subsection{Informed Consent}

Formal and written request to use clinical data, was made and subsequently granted by the facility so that I could begin data mining. I am using a qualitative secondary analysis of my own clinical notes and reflective diary journal, so there are no 'participants' whom I needed

to obtain consent from. Every effort was made to carefully minimise client identity risks, and for myself as a student researcher. It is possible for the specialist features of my clinical placement to be recognised due to music therapy's relative 'newness' as an allied health profession in New Zealand. And so there may be risk of clients being identified.

Every attempt is made to protect client identities as well as staff teams who kindly supported my placement. Consents were obtained from the facility via letter, to a third party, (parent), and staff member, or spouse on a facility form for the Case Vignette within this research, and on Te Koki NZSM school letterheads. Every effort was made to maintain client anonymity.

There were two clients who wished to be identified, or whose whānau "wanted their story told." I have tried to meet their requests sensitively. All clinical data was held in a secure place, and a password operated computer. On the completion of this research, it shall be held securely at the NZSM Music Therapy Faculty. 


\subsection{Code of Ethics and Ethical Approval}

This research was given ethical approval for, the Master of Music Therapy students seeking to engage in observational studies or case study research by the Victoria University of Wellington Human Ethics Committee (Ethical Approval Application \#22131). I abided by the Code of Ethics for the Practice of Music therapy in New Zealand, (Music Therapy New Zealand, 2012), and the code of ethical conduct of research teaching and evaluations involving human participants, (Victoria University), throughout the research process. Secondary analysis of data obtained from usual clinical work falls into the category of observational studies (i.e. there is no deviation from usual practice).

\subsection{Dissemination of Research}

This research will be available from Te Koki School of Music Therapy, Victoria University of Wellington, Aotearoa, New Zealand. 


\section{CHAPTER 4: FINDINGS}

Findings showed that an important concept was the 'musical space' - as a 'place' that contained the co-created music between the client, whānau, staff teams and I, (Kenny, 1989, 2006).There were clear examples within the data that my SMT practice is underpinned by the FWCMT approach, and Community Music Therapy.

These two approaches informed and motivated my developing understanding and commitment to the MT space belonging to the client, their whānau, and staff team explain why I was highly attuned to the client's non-verbal communication and so was motivated to facilitate opportunities for clients and their whānau to 'meet' within the musical space, (in waiata, playing instruments, or in karakia in song). For example, when the client's whānau were not present in the music therapy session, their whānau's 'presence' was brought into the musical space by the client who either verbalised how much they missed their spouse, parents, siblings or children, or who composed a song or rap for his daughter.

This then led to a client talking about their sibling or parent, or to a lyric-substitution of their loved one's name within their chosen waiata. It could lead to the composing of a short waiata about their love for a spouse. The following list of five main themes of 'space' contained the music therapy experience in my student music therapy placement, and seemed important in demonstrating the FWCMT approach.

The main themes are highlighted by bullet points, to be expanded upon further below:

1. The spiritual, psychotherapeutic, physiological health well-being of the Self;

- Clients were enabled to remember or to see themselves as more than a 'client' or a person with a TBI.

- Music 'held and contained' difficult emotions for whānau and clients.

2. The internal space - foundational space of the client and family-whānau gathering;

- Whānau and clients communicated through shared music-making. 
- Whānau and staff carers attempted to support clients' musical exercises to support activities of daily living.

3. The maintaining the dignity of all -the client and family-whānau, including respect of the music therapy space;

- Whānau and clients experienced feelings of 'hope,' 'safety,' and 'belonging'

- Sub-theme: Intergeneration relationships.

4. Boundaries: The collaborative external space - visiting family-whānau, the interdisciplinary team and staff carers who became the 'institutional familywhānau,' or extended whānau of the client;

- Challenges to recognise and to engage in new ways of working with the Self, clients, whānau, each other; i.e. Boundaries - belonging to whom?

5. The mita - rhythmical foundation of the Self - the innate musicality, external structures, influences and rhythm found in whenua and cosmos which has formulated, influenced and supports the internal-external rhythmical cultural self.

Whānau relationships were enhanced through the mealofa or 'gift' of musicking. In our training, we learnt of the music-making space which becomes the container for the expressed emotion of the client, (Bruscia, 1991, 2014; Bunt \& Hoskyns, 2002; Kenny, 1989, 2006). Like many cultures, Polynesians are brought up never to go "empty handed" when visiting, or a guest. It was a refreshing challenge to accept that "the music is GIFT enough."

It was clear throughout the data that on my student practice I experienced the 'musical space' as being able to transcend boundaries belonging to the place, time, or limitations of the client due to their injuries as it were. But that I was only able to 'see' this space during the data mining process. The mealofa of music therapy is a fale tele itself!

The following (figure 4.), is the illustration of the aforementioned Samoan Fale Tele metaphor, encapsulating the MT client's Personhood, theirs and their whānau's 
musical space, their spiritual, psychological and physiological Self. It also situates the trusting

relationship between client and staff who became their 'institutional family-whānau.' Parallel links between the Samoan fale tele metaphor of health and whānau centred approaches within music therapy perspectives, were hugely advanced due to discussions with my supervising lecturer, and the work of Carolyn Kenny, Music and Life In The Field of Play, An Anthology, $(1989,2006)$.

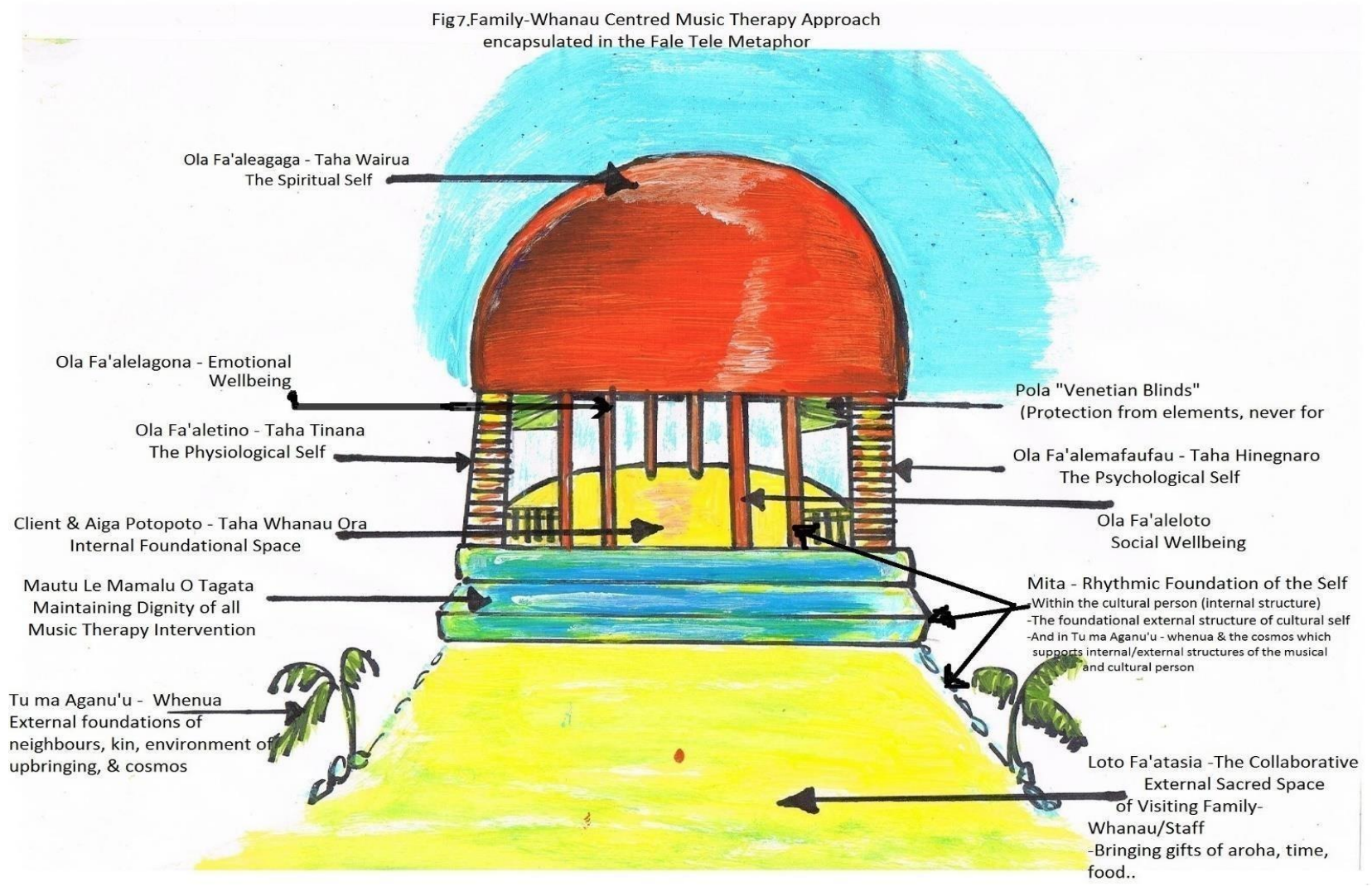

Figure 4. Samoan Fale Tele metaphor encapsulating the personhood of the MT Client

\subsection{The Spirituality, Psychological, and Physiological Self}

- The spiritual self - wairua, the flourishing mauri and wellbeing belonging to the client and whānau. The emotional, mental health and physical health of the client, and their whānau.

The FWCMT approach provided a musical space for whānau to verbalise emotions or inner feelings of surprise at their loved one's musical expression, lyric analysis, 
memory recall or the sheer joy of seeing their loved one 'happy.' It also provided a clearly demarcated space where a prayer could be 'said' for clients that was received either silently or with tears of 'relief and happiness.'

I was quite anxious about this aspect of karakia, and was very careful to ask or to gauge client's responses, or speak to therapy teams in case there were clients or family who objected or may become upset at this ritual. But in the eight months of my student music therapy placement, I observed palagi clients, (whose clinical records stated they had no religious affiliations), accepted or even sought the chaplain's prayer, or an elder client's prayer for themselves and their family. It's uncertain if this was due to the MT space, or that they felt comforted in the group ritual?

It seems there is an inter-relational connection between a flourishing mauri and wairua, and a client's hinengaro and tinana.

- For the clients in this study, as time progressed, and all eight People seemed to regain cognitive function, or in physiological strength, the data showed that there was a parallel increase in their observation abilities as well. Clients began detaching from the facility, looking towards home.... their whānau members to give them a sense of safety or hope.

- I wondered if the clients' insightful abilities were heightened as the body compensated for this physiological injury. There was a responsibility to be alert to every nuance from the client, and their own interpersonal relationships with whānau or staff - to support their inner state communicated through music or vocalisations.

There were moments when I felt like the interloper; or as the case with "Hess's" daughter, (whom I met only once during the three months I worked with her Dad) - as a 'frivolous' disturbance in the midst of their 'serious suffering and pain' even. I observed this in her eyes as they frowned at first sight of me holding a guitar and hand beaters in the doorway. It was not until her father smiled and laughed saying "Yes, yes," that her expression, lightened, and the door was opened wide. When leaving, she indicated for me to join her in the corridor.

- Hess's daughter shed tears sharing her relief at witnessing her Dad "being able to find comfort in music;" and tears of stress as she shared about the pain and suffering her parents were experiencing due to their being too ill 
to visit with each other. This was the only opportunity that we met, but because of this meeting, Hess's MT sessions always ended with a karakia for this daughter and her children, (whose large family portrait was affixed onto his bedroom wall), where he would look at them and lead a karakia "for my daughter and mokopuna." He would also lead karakia in group MT; or he requested a prayer from the facility chaplain for them.

\subsection{The Internal Space: Aiga Potopoto o tagata: Family-Whānau}

The internal space, contextualised the client with their immediate whānau. Belonging in this space also, are the nursing team, the rehabilitation workers and care staff who clearly formed close interpersonal relationships with the client, and so become attached to each other - in the 'institutional family-whānau.' Within this internal space, it seemed that the FWCMTA was demonstrated when:

- I actively encouraged, or gave a choice to whānau members to participate in music therapy sessions alongside their loved one. I observed that whether or not they were 'joining in' the music making process, (via vocalisations, eyebrows raised up and down, smiling, humming or chanting) -to sing, playing music instruments to generate rhythm, expressive sounds, beat or melody and harmonies, their very presence was important for the client.

- A client's level of enthusiasm and motivation increased.

- They smiled more, become relaxed, confident, enthused and motivated to 'have a go' at playing an instrument.

- One young client started to 'teach' her baby sister how to play the instruments that she herself had been playing. I noted in my reflective journal:

\#5 ... suddenly in that interpersonal interaction, 'Janey' became a confident young person - (different from the young client whom her therapist informed me didn't feel confidence in her music ability). They were smiling at each other and playing together, whilst I just kept playing guitar' to support their musicking... I also observed their 'mum' looking on, seeming overcome with emotion. 
Whānau in 'witnessing' this 'enjoyment' also shared with me that it helped them to sustain hope for a 'positive future.' This was especially true for the research participants discovering a 'new way' for themselves to still create music (if they were musicians prior to their $\mathrm{TBI}$ ), or to regain motivation for the rehabilitation exercises. For example, when clients are observed by loved ones as they play music instruments, they see the client tapping foot/hand, playing sustained beats with a drumstick or clasping a large shaker, (Baker \& Tamplin, 2006 p.78), whilst previously this hand seemed impaired, weak.

These musical exercises can translate into a client being able to clasp a bar of soap; a kitchen utensil e.g. as a spoon/ladle. Once whānau or client witnesses this playing music instruments, movement of limbs to a beat or to dance, implicit shifts seemed to co-occur. "Success in musicking" is encouraging, (see fig. 2 with "Mrs L"); seeming to visibly motivate whānau towards a more active role in their loved one's rehabilitation, or to encourage the client to engage in a committed way in their physiotherapy.

\subsection{Boundaries - The Maintaining the Dignity of All Tangata Space}

- Teu le vā: Mautū le mamalu o tagata

- Maintain the dignity space of/for people.

- Boundaries: Respect for the implicit self and family-whānau's mana ensures you will be less likely to show disrespect, or exploit your power, (whether, you are staff or client, or student music therapist).

Maintaining the dignity of the person and whānau is a given for this or other music therapy approaches. Doing so ensures one maintains all other boundaries pertaining to the person(s). This involves following facility protocols, the laws of the land, but if even those are not sufficient, then those of lo, or Mother Universe, God.

On a personal level, the data revealed that within my student practice, this seemed to be the musical space that a reconciliatory concept of ifoga, (Samoan forgiveness/restorative justice ritual), interfaces with the moving ritual of the Māori hongi; so that restoration of a person's mana, or maintenance of human relationships, intermingles with the exchanging of gifts (of time, aroha or foods, as one of the clients 'Hess' speaks of further on) 'space.' It transforms the Collaborative 
space. It had become the 'space' on placement with client, whānau, staff or visitors where the FWCMT approach, was effective, comfortable and needed. A space where or when clients and whānau need support the most - where there is often shame from loss of cognitive function, physical strength, position in whānau/community, or - loss of a loved one - maybe someone else's loss of a loved one? This is the space that often holds and contains a lot of dis-comfort, or dis-ease. ${ }^{1}$

The 8 clients of this study all had various experiences of 'separation' from their whānau due to a spouse's illness which prevented their being able to visit the facility, historical personal family events, or geographical distances of overseas, or around Aotearoa. Whilst the evidence is inconclusive, there were clear examples of clients, whānau or staff being able to:

- Engage and entice the client and their whānau into a communication through their combined musical experience. They seemed to experience a meeting through the music.

- Provide an inclusive, comforting, motivating construction of music beats, waiata, and improvisational musical interaction between myself, family-whānau and staff- that clearly motivated the client to smile, sing, move to the beat, in order to communicate their inner state, or to help clients organise themselves physiologically - to verbalise words clearly which may not have been possible before this.

\section{3(i) Sub-Theme: Intergenerational Interactions}

I observed the above examples further demonstrated during group MT, when the structure of the session - the opening and closing of sessions with a hello/goodbye song, enabled clients to transcend the intergenerational or gender boundaries. Clients could greet each other as they engaged in the hello song, or in the caller response segments of the music instruments playing or turn taking. Younger clients, (especially Māori and Pacifika Kiwis), showed the 'polynesian way' of respectful interaction towards the MT group's older clients by the way they spoke to them, and in the way

\footnotetext{
${ }^{1}$ I attribute this learning to the late Dr Pa Henare Tate, Maori Theologian \& Auckland

University Lecturer, who expanded my Parent's teaching - and opened my wairua to the needs of every single person on this earth's mauri - and the need for all Tangata to reconnect
} 
they supported musical expression from the men whom they addressed as "Kaumātua."

It seemed this respect communicated itself to the older Māori gentlemen and through their connection with the youth, the Kaumātua were enabled to then respond by completing a mihimihi or karakia in te reo Māori, (when prior to this "Hess" was unable to remember his name); or for "Howard" to communicate a speech in English followed by his leading into a Māori hymn/waiata, e.g. "Whakaaria Mai,"

\section{3(ii) Sub-Theme Howard's Teachings for an SMT - a Tribute}

Another example demonstrating the FWCMT was provided by an individual MT session with a client named Howard and his children. I had arrived to find his sons were visiting. An instinctive reaction was to withdraw and allow Howard and his children some whānau -time. But the FWCMTA means that I must provide 'an opportunity for choice'- so, I paused for staff who usually beckoned me to stay and support, to indicate 'stay' or 'go.' Our training discussions with my supervising lecturer noted that sometimes whānau welcome "something to do" together.

I realised also, that such a rare opportunity due to the client's whānau living out of town, or visiting primarily during weekends when I was not onsite - should not be missed.

This was the client whom I had first advocated on behalf of, in direct disagreement with a new staff member, (who later left the facility). She had been labled him as "probably a violent person pre-TBI and a suspected domestic abuser." I had never experienced this situation before, and realise now that I should have attended the meetings to further discuss this in a more rational and lucid way. To be fair, the previous facility had written a negative report which they were repeating in the office space and I overheard the discussion, and objected verbally. We continued to disagree whenever the subject arose.

Many months later, the facility was given a different report, which revealed that Howard's TBI, resulted from a routine heart operation, on a very fit and active 50 s sportsman and coach - had changed him almost beyond recognition. He was known widely to his community as a very loving family man, who worked hard all his life, and 
was a dedicated volunteer, mentor, coach at a very prestigious Māori College, where he had also been a much loved Chaplain. He had once often led karakia and waiata with his guitar, and rich singing voice.

However, this excerpt was long before we knew any of this:

\#48 Singing welcome song \& functional phrases with his children present was poignant moment

\#49 Client's son playing guitar accompaniment for his Dad...Son shared music on the guitar for his Dad. Dad tapping his toes and then feet to his son's guitar music.

\section{Figure 5. Example of intergenerational interaction}

On this occasion there was a semi-stressful air as the bureau-staff, (not his usual Care Staff), were trying to complete cares in a way that enabled Sydney's whānau who were clearly wanting to be more involved. Howard in turn presented as stressed by the busy-ness around him. MT seemed to relax and shift the focus slightly, and to have an organising effect on his fine and gross motor skills - just enough so that his children could work together with the staff.

Knowing from previous sessions of his acute homesickness, and how much he yearned for whānau and whēnua, it was poignant to witness his children helping Dad to put on his socks, administering daily cares, evoking strong feelings within myself as well. Being able to play a simple melody to accompany their whānau's poignant moment did help me to contain my own emotion, in order to focus on supporting them. As the music finished, I waited in silence to enable Howard and his children to experience the full gamut of emotions, and the tenderness displayed by his sons towards him. I felt this was an important aspect of MT and the whānau centred music therapy approach - to support their whānau goal as noted in my journal:

\#143 To encourage and strengthen, or to help maintain whānau bonding between Howard, and his children, so that their ongoing journey (postrehabilitation clinic), is one of continued aroha, and hope for the fulfilling of their whānau's dream - to get Dad home.

In light of this also, I invited his sons to play a "number for Dad" whilst we went through Matua's musical exercises for his lower and upper limbs - supporting the 
work of physiotherapy, via the motivating elements of live music. On this occasion I hoped to model another way through music that Howard's whānau could support him when he discharged. The following extract is from my student journal:

\#149 It was hard to stay focussed and not choke up myself when his sons' seemed "choked up," but I had to harden up so that they could enjoy the sacred experience of serving their Dad... After a moment of silence one of the sons shared that he wished he could come and do this more with Dad... but distance and having to care for his Dad's farm doesn't allow it. 'Observed Howard seemed to be listening intently, perhaps processing cognitively as he was "overcome" turning with difficulty towards his son ..he could only make a low sound... I took out his folder of functional phrases which my clinical supervisor, had asked that we sing, when Howard was referred for MT.. By the end of these, he looked at each of his sons by physically turning towards them with some difficulty when he said their name they came closer making eye contact - saying to them "I Love You....." His sons were crying, the son's girlfriend, me too... couldn't stop the tears. 'Made eye contact with Howard, smiled at his quizzical look saying: "I have tears because I feel happy and honoured to share this moment with you and your beloved sons." Howard nodded and settled back into his armchair. I asked (son)- if he would play a favourite song he had shared in the past with Dad - whilst we concentrated on some fine \& gross motor control exercises... was profoundly moved when he played something that he had composed in "happier days" he said.

I was careful to take such moments to supervision with my MT Supervisor, discussing transference and counter-transference or psychotherapeutic issues that might arise out of my MT practice. I found that having this supervision available both the facility onsite and from the profession of music therapy as both soothing (assured client safety with having a professional "eye" on my actions) and challenging, (examining my motives for my own behaviour to ensure client safety).

\subsection{The External Space}

- Loto Fa'atasia - The Explicit Self (interpersonal communication and social ability) Gifts exchange: of time, good intention, musicking between client \& all 'others.' 
This is the "space" where I found the extended whānau, (friends, relations, estranged or disconnected whānau visiting client and his/her immediate whānau), therapy teams, household staff, chaplain, management team of the facility are located.

Data and journal notes showed how whānau help contextualise the client through their shared history. If the client is experiencing challenges with speech and language, their whānau can interpret, or - they spoke to client on behalf of the health professionals. In a sense, when it was working positively the whānau provided the client an enabling confidence, a sense of identity, and a place of belonging - and so with much needed stability.

MT that facilitates music that is grounding to support the interdisciplinary team's work to reorient a client to their surroundings, memories, whānau - to their land, can immediately support clients and whānau.

This was another way that anchored/helped the client to remember or see themselves as more than a "dependent-client," which was such an important factor in their rehabilitation. Clients reached towards their whānau's voice, hands and vice versa, demonstrating often the powerful healing presence of whānau presence - and their much-loved voice:

\begin{tabular}{|c|c|c|}
\hline Client & $\begin{array}{l}\text { Client Identity strengthened through singing } \\
\text { homeland waiata with her whānau }\end{array}$ & STM Reflective Diary \\
\hline $\begin{array}{l}\text { Young } \\
\text { mum }\end{array}$ & $\begin{array}{l}\text { \#181 Her Dad was there... He seemed moved by the } \\
\text { experience of playing guitar/ukulele to his daughter... } \\
\text { calling out her name as he bent in front of her wheelchair } \\
\text { and sung to her in their mother tongue... He followed this } \\
\text { up by leading songs from their homeland which seemed to } \\
\text { make the whānau tearful as they clapped, sung and } \\
\text { danced. (It is also the first time that these usually stoic } \\
\text { looking Proud Polynesians, have relaxed and allowed } \\
\text { themselves to sing, clap and dance in a public space). }\end{array}$ & $\begin{array}{l}\text { Her tears dried during } \\
\text { what seemed a very } \\
\text { special time (making eye } \\
\text { contact with her Dad \& } \\
\text { smiling, listening to him, } \\
\text { her eyes opened wide, } \\
\text { singing together) }\end{array}$ \\
\hline
\end{tabular}

Figure 6. Example of how whānau presence strengthens client identity

What seems clear, (as illustrated above), is how one's cultural music can support the relationship and interconnection between a client and their "estranged" whānau. It is also motivating for family-whānau, lifting their spirits enough to relax as depicted above. FWCMT was further demonstrated in the way a client's spouse, parent or 
adult offspring were able to confirm client self-revelations as factual, something at first disconcerting: that even when clients speaks confidently of a past event, or future plan - I needed to learn to always check with the interdisciplinary team to ensure factual recall.

Another example of the FWCMT revealed in the data belonged to a Kiwi-European family, between 'Henry' and his father. Music therapy seemed to provide a 'bridging' effect for the client and his Dad. I had arrived for the scheduled music therapy session to find the room full of visitors, three adult visitors, a toddler and staff members who left the room as soon as I arrived. I had felt an undercurrent of 'awkwardness' but was not sure if it was an existing environment irrespective of my presence, or because I had interrupted a family gathering and they were impatient to be left alone. As I was apologising for 'interrupting' and turning to leave: Henry himself asked me to stay. Henry declined saying 'no' to playing an instrument, yet l'd seen his arm had moved as if he was about to 'reach out' for the tambourine which he had enjoyed playing and being challenged to use his affected hand, (previous session). I was careful to keep Henry's face in my line of vision as I offered a choice of instruments to Henry's Dad, who reached for the bongos saying: "I've never played an instrument before," laughing 'nervously.' I wrote in my reflective journal:

\#45 This soon changed due to his father's accepting of the bongo drum. Father and son become genuinely enthused ...followed by a discussion of heavy metal music and the shared interests and tastes they both had. Although there were five adults (including staff), in the room, there were moments during turntaking which supported the father-son relationship, as they maintained prolonged eye contact with each other. Later the Therapy Team shared that Henry's parents were separated which meant complexities around visiting times.

\section{4(i) Collaborative challenges - The SMT's Boundaries}

The data showed that even though music therapy sessions were planned for clients in collaboration with the Multidisciplinary Teams, or consultation with whānau with facility goals and objectives, we had to be open towards the client's ability to surprise. The MT session plan is dependent on the severity of the client's brain injury - but addressing the cycle of needs within the whānau as a whole is just as important. Then, 
it may be that the musical experience is facilitated to support and sustain the whānau's capacity to continue with their caring role towards the client transitioning "back home."

One salient point for this paper is how 'boundaries' presented a personal challenge. They were called upon when I was not practising good self-care. Both my facility supervisor, and visiting MT supervisor endeavoured to ensure I maintained healthy boundaries; to work sustainable routine hours, build up good habits of nutrition and exercise when I became unwell. In the beginning of my placement, I did not realise that I was supposed to attend certain meetings, (previous placements had not allowed this). I would have been able to request for the facility's whānau meetings to take place whilst I was on site, or asked if I could attend weekend meetings.

I often found myself wondering in my student practice: 'Boundaries' whom are they meant to protect? The client or whānau or staff, or therapist? I found that when I as the student practitioner, maintained healthy boundaries to teu le vā, (maintain the inbetween grace-space), then all 'are protected.' However, what if there has been a violation of the sacred thresholds surrounding the family-whānau and client? When the moral and cultural laws interface with the violation of state law? When there is a break-down of self-control, self-respect and mana-tapu for one's self, and for others, that has led to family violence? Half of all homicides in NZ are committed by an offender who is identified as 'a family member.'

One in three women experience physical and/or sexual assault from a partner in their lifetime; or are seriously assaulted during a time they had intended to leave a violent relationship, (Family Violence It's Not Ok, areyouok.org.nz; Statistics NZ (2015) NZ Police recorded crime and apprehension tables).

Data shows that these elements of family-violence on placement were personally confronting, given that I was involved in a harrowing case to bring a whānau member to court. It was a new experience on placement to try and maintain a clinical boundary, to leave the rest to the justice system. This following Client's tragically severe brain injury was caused by her husband's hate-crime/violent attack, left her profoundly physically, mentally, emotionally, and spiritually near death. The data 
shows how staff and I, felt a sense of elevated responsibility, connection to her in the following section.

\section{4(ii) FWCMT Approach With Courageous Survivor}

MT seemed to provide a bridge between *Serena, (not her real name) and her much loved children whom I never met. Her aroha and yearning for them was ever present as her eyes would move to their photos on the wall during sessions. Music also seemed to bridge the gap between whānau who were estranged due to historical events, or geographical distances, (please see Appendices 8 (a) and 8 (b).

There were complexities when Serena first arrived, around her whānau visiting, given that her life threatening injuries resulted from domestic violence. As the client, Serena's care and safety was of paramount importance to the facility. Music seemed to provide comfort, healing, space. As time progressed, there were many instances highlighted via the data, of music being a bridge between family and Serena; as an outlet for singing between staff and client; or discussion between staff and whānau regarding the client's preferred music. I worked closely with the client's OT and SLT who had referred her for MT to reduce anxiety, to relax a muscle spasm habit. It was hoped that MT would also provide some comfort and lift her sadness and stress at being parted from her children.

- As our therapeutic relationship grew stronger, she shared about her inner state through Beyonce's waiata: “Ave Maria” (I Am Sasha Fierce Album, 2008). Although barely mobile, she had to press the right song (frowning and making a minute shake of her head that seemed so painful). When I asked her why she chose this, she could barely speak due to her injuries - but said in whisper: "Those are my lyrics."

I had been so focused on our session that I did not realise staff had come into the lounge until I heard a shouted squeal, and indrawn breath, because of her sharing. Understandably, there was disbelief from the psychologist (understandably I knew), and some even said "...you're making that up, it can't be true."

- The client's therapy team, nursing and care staff demonstrated high regard for the client, to "awhi" the client. There was a special 
bond and trusting relationship between the client and another staff carer who was of her nationality. This staff member was often present in those initial first sessions which I felt was helpful to the client and I forming a therapeutic relationship.

- Or did we all have an instant rapport due to my being a PASIFIKA woman as well? In short, there was an acute extended-whānau feeling emanating from the staff towards this client, which was like a physical embrace that I became part of - and it remained during the session.

Nursing staff and carers were ever present during the client's individual or group MT sessions. It was a palpable experience and example of the staff, (from diverse and disparate cultures), becoming THE 'institutional whānau,' extending aroha and great compassion to this client. On one such individual session which took place in the lounge, staff presence during the musicking seemed to enable the client to surprise herself, as well as two other clients in the room and the staff team of three: care staff, nurse, and the Cleaner, who after this experience became my biggest helper and friend. When the client smiled widely and laughed aloud, the staff were 'galvanised into action.' The male staff member playing the djembe vocalised a pleased expression, his drumming changed from a 4/4 to a syncopated beat whilst he began to sing a bass harmony. With the other voices joining in, staff members playing a maraca, another a tambourine, and still another dancing. I played guitar, singijng - a four-part harmony arose. I felt that this was why the client's laugh rang out (the only time I did experience her doing so).

Serena often presented as deeply fatigued from her TBI, melancholy, due to physiological and what I termed as her intense 'psychic pain.'

- The song was the African hinterland Mbube, or Wimoweh, (1939) or better known as "In the Jungle," (Solomon Linda \& The Original Evening Birds). Although this song became a favourite, this was the only time when there was a Zulu flavour. Again I observed that although the client eventually closed her eyes in the third verse, she continued to 'mouth' the lyrics correctly, smiling widely.

I hoped that this "action" would be sustained and whether the collaborative work that unfolded would continue to enthuse staff and client. I concluded that if the client seemed to feel that these areas of her mind, body and spirit are increasing 
in strength, or developing on a functional if incremental level, hopefully it may improve her psychological health and wellbeing. Building self-esteem seemed only to be possible with this client when her cultural identity, (encompassing the spiritual, emotional and mental wellbeing), 'felt' supported during the session.

Previously we had sung songs from her country of birth with staff from her homeland. I learnt a lullaby in her language which she remembered and "mouthed" the lyrics. However, I was unsure if the lullaby was a comfort or not due to never having attended whānau meetings, or remembering to ask other therapists to find out.

\subsection{The Rhythmical Foundation of the Cultural Self}

- Innate musical self of the client, and whānau - of all people

- External structures, influences and rhythm found in whenua and cosmos which

supports the rhythmical structures of the musical cultural self.

Without rhythm, there will be no form, no structure, no animation, movement or direction - only chaos, (Brooks \& O’Rourke, 2002 quoting Puoho Katene 1991). I was ever mindful of the invisible time and space parameters of the Client and his/her family-whānau, present within and without the environment of the client. I acknowledged these "cultural rhythms" whenever I arrived on site, by doing a small grounding ritual and karakia - thanking Atua for the opportunity to be with all here, especially the clients and family-whānau, and asking Spirit's help so that I may be truly present to their Wairua.

- For clients sharing music therapy sessions, there seemed to be a comfort and relief, whenever they were in the process of musicking with those who have a shared history with them, staff or whānau.

- Grandparents, spouses, parents, siblings, offspring, friends, extended whānau, and staff who had bonded with the client - were people who seemed to instil a feeling of safety and confidence into clients which enabled clients to participate more positively or even become motivated to commit fully in the music therapy experience. 
Surely the data reveals how client and whānau freed the music within themselves. Kin, neighbouring clients, visiting friends or staff all responded to the rhythmic pulse and beats emanating from the client or family-whānau - to entice a musical communication from the client. Serena's data highlights how her music, relationships with therapy teams motivate the client to engage therapy exercises, e.g. use of a drum stick to play a beat (strengthening fine motor control to perform daily tasks of living such as holding a utensil during meals), or raising of fingers.

\section{5(i) Hess's Rhythm}

For instance, after eight weeks of music therapy sessions with 'Hess,' and after collaborative discussion with his OT and Physiotherapist regarding his physical progress and how MT could further support this - it was suggested that it would be helpful if MT could encourage Hess to independently operate his wheelchair. Hess's data shows that he was highly attuned to world music, receptive to music therapy, and was extremely motivated to use drumsticks and hand held drums to the song: "When Johnny Comes Marching Home again hurrah! Hurrah!" (Irish-American bandleader Patrick Gilmore in 1863), a popular song of the Spanish-American Civil War 1898.

The strong down beat strum on the guitar and vocals was to provide a rhythmic auditory stimulation to support his lower limb motor control to enable him to tap, then stomp his feet in time rhythm and movement and build up strength. During the lower limb exercises he did not sing. Lyric substitution did eventually occur...once he moved his toe, foot...he became enthused and when I inserted the lyric "when Hess lifts up his leg hurrah hurrah" ... this enticed a larger muscle movement.

If Hess had the energy to continue, I used a paddle drum and tambourine drum (which he liked to run his hand across and play the side bells). Or I would hold a large djembe or the bongo drums, and move this from side to side. The song was again utilised to support his upper limb - through drumming two beats on the left (on a paddle drum I held), and then two beats on the right side on the "hurrah! Hurrah!" Later his rhythmic timing seemed consolidated and Hess was able to complete the double-beat drum and sing the words, sometimes he sped up, (laughing aloud as I matched and followed his lead), before finally slowing down to stop. 
- Although Hess's whānau were not present, as we begun to sing his closing waiata, his eyes again went to his family's photo. He initiated a karakia for them after the waiata.

- Hess never had a "traditional" whānau session, had PTA, yet, at every session he spoke of his whānau, recalling earlier memories of his youth, when he married, had children - but only after a waiata from those years. This often led to his request for karakia for his beloved wife, children and mokopuna.

- Hess challenged my own perceptions on what a family-whānau centred MT session should "look like," because prior to this research, I only imagined FCMTA as a client with his or her family-whānau alongside them in the music making space - participating, or just being physically there. 


\section{CHAPTER 5: CASE VIGNETTE}

For this vignette I describe my SMT practice with a teenager named Janey ${ }^{2}$ to summarise my findings, as her 14 MT sessions saw Janey improvising, or sing-speak alongside her parents, Koro, siblings or cousins. Janey was referred by her SLT and OT, for music therapy to support her mood, self-confidence and life quality. Janey's whānau lived at the facility due to her age. Our first meeting was at a group MT session. I observed how much her parents enjoyed the session, with her mum, (who could play "anything" by ear), choosing the guitar and sharing her wonderful musicianship, smiling, laughing and encouraging Janey, to also choose an instrument.

- It was then that I noticed Janey watching her mum proudly.

- They both smiled at at each other, it had an effect on Janey moving her body instinctively, laughing carefree. Yet both did not sing, or vocalise except in laughter.

- Mum shared that it was "so good to play a guitar again."

It required me to be culturally aware, supportive and respectful of Te Reo

Māori and Janey's whānau protocols, especially when her Koro was visiting. Polynesian traditions of not sitting on tables (a place to share food), or a pillow (where the sacred head lies), meant being even more careful in the bedroom space. It is home away from home. Yet, besides being a young Māori teenage girl, whose positive attitude earned her the respect of everyone - Janey returned their regard, developing a real interest in others and their INDIGENOUS languages, especially French, Fijian, Samoan.

\subsection{Background Information}

Janey had been involved in a horse riding accident, with her horse rolling upon her causing severe TBI. Doctors said the impact of her brain injury would result in long term effects on her physical, cognitive abilities, and so may impact her emotional wellbeing. At the time of her referral, Janey used a wheelchair. Janey's SLT and I were able to work collaboratively in the first few sessions. Janey was very motivated in every therapy offered on ${ }^{1}$ and off site, to aid motor rehabilitation and cognitive

\footnotetext{
${ }^{2}$ not her real name, and is a pseudonym
} 
function as she had very little lower limb function. It was hoped that music therapy sessions would support Janey's emotional, mental health, and provide:

(1) Support for her positive spirit and attitude, and to support her parents who have transferred their household from out of town, living in the same bedroom unit as Janey. When I met with Janey and her parents, they added the following goals.

(2) Support for Janey's left hand's physical function.

(3) Promote Janey's self-confidence;

Janey herself then added:

(4) To learn Samoan, or other languages, to learn the ukulele!

Janey's parents sought me out on a separate occasion to add their heartfelt wishes:

(5) For Janey to regain her vocal singing kapa haka ability/confidence to lead this again;

(6) To enable Janey's return to kapa haka activities after transitioning home.

Unfortunately, the weekly group music therapy time clashed with physiotherapy sessions, Janey rarely attended group. I approached the team informally, and asked if it was possible for a half hour shift on their part so that she could stay for half an hour rather than 10-15 minutes. Her physiotherapist replied that after my first request, he himself had asked Janey if she liked group MT sessions, and she had replied 'no, I prefer my individual sessions'... so understandably he saw no point in changing an already busy schedule.

I felt that this 'frustrating impasse' hindered progress, due to the rare occasions when Janey was able to attend Group MT with her parents, Koro, siblings and cousins - she invariably displayed an unselfconsciousness free flow of wairua!. She seemed to revert back to being the 'older sister.' Janey would begin instructing her whānau, even her Koro - on what instruments should sound like (due to her having played them during individual sessions). Or she would point out which ones might suit whomever and "to have a play/go - go on!" she would call out.

At other times she would be instructing them how to sing and where they should stand, or where to sit in the room, and to "stop tutuing with that!" In those moments Janey would present as the young kapa haka leader, she must have been, laughing 
aloud as she 'bossed' her whānau around the MT space. Her eyes would take on a clearly assessing their "performances" stare. Then Janey would either nod proudly at her Koro, or shake her head at her baby sister or cousin with a" tuttutt" sound! Her musicking with her 'mum,' father, or with her Koro - also visibly had a joyous effect upon her whānau. They too seemed to forget their worries whilst choosing instruments by exploring their sounds, and then turning towards Janey - in play, and in fun.

I only glimpsed this refreshing sight of Janey, on the rare group MT sessions she made, or when whānau visits coincided with her individual MT session. Whānau presence had a positive effect upon her with a reciprocal flowing support dancing between client and those who loved her, until you couldn't tell whom was motivating whom?

\subsection{Family-Whānau In The Music Therapy 'Space'}

Janey's parents were present at her first MT session, and there was an atmosphere of expectation, (tidying up, putting on clothing). As this whānau rarely left the facility, it seemed important to always offer opportunities for Janey's parents to also choose to say "No" - I asked if they were going out, and that perhaps I could return when it was more convenient?

"Please come in!" call her parents, "We're tidying up to make space for you!" As noted in the data, during this first session three significant revelations were shared within the context of the music making between Janey and her parents:

1) Janey's Dad shook his head saying "I don't know how to play music" whilst holding a bongo drum. Yet he immediately seemed to engage with his internal mita and beats in response to his wife strumming the guitar, Janey's improvisational playing and vocalisations, as he begun drumming rhythmical patterns that caused Janey to turn towards him saying proudly, laughing aloud, then giggling, “Go Dad! I didn't know you could play!"

2) New information for the therapy team, is revealed whilst Janey is playing the egg shaker - "I'm so lucky to have my step-mum to play music...." And when they exchanged a warm smile, Janey said to me that she had been 3 years old when her mother had passed away. 
Due to this open hearted sharing Janey almost burst out with "...please can you teach me some Samoan waiata? I've always wanted to learn Samoan, and maybe other languages too... I love listening to other people speaking their language around here." Janey's parents give an animated affirmation of her linguistic prowess, and I observe Janey 'pleasure' at their affirmation and tautoko as she aids her cognition by acquiring language through song.

- Janey's step-mum admits she also wishes to learn. They share a surprised smile with each other, and for the duration of Janey's time at the facility, languages from the pacific are incorporated. E.g. inserting "Bula Vinaka" into her hello song, because she wanted to learn this Fijian greeting to surprise one of the staff whom she thought was "very cool."

- Janey was unfamiliar with Frere Jacques, so this became our French waiata.

- When Janey's sister came to visit, Janey taught her some of the chords she had learnt - her sense of achievement, of agency and pleasure was a direct result of the FWCMT approach.

- In order to encourage Janey to maintain her love of Kapa Haka, and to support her cultural identity, I asked Janey and her sister to share their sacred pepeha with me, before we sung one of our Te Reo waiata. I knew that having her sister in the MT session was the key to Janey speaking aloud her proud heritage as Tangata Whenua, which in itself I believed to be a great healer for her wairua and hinengaro.

Another aspect of the FWCMT, was the informal parental "meetings" when Janey's step-mum and dad would share their goals for their Girl of "get her selfconfidence back, and take up her Kapa Haka! She loved it so much".... Or they would give me feedback about other therapies they were participating in. It was in this "busy space" also that they made a request for "something to do" for their other children when visiting. They wanted their whānau to experience what they had experienced - "it was so different from other therapies!"

Whilst the FWCMT approach, was demonstrated as motivating in the sessions: \#14-15 Janey \& Whānau (Stepmum \& Dad) just returned from hydrotherapy. Consented to MT in bedroom with all of them participating. Janey on egg shaker, parents on ukulele \& bongo drums again.. Janey presents as tired but seemed keen to play with her parents especially her Dad. 
There was also a time when Janey's father was on a prolonged absence due to a sudden whānau tragedy, (please see figure 7 below):

Janey's stepmum preferred instrumental improvisation to singing. When this time of bereavement happened to their whānau, the following day, she was clearly grief stricken by her nephew's suicide and her own yearning to return to home for his tangi. She had chosen to stay with Janey back in Auckland. I asked her if she would like to have the guitar for a few days, and her reaction was profoundly moving-giving me an insight: the guitar was a non-verbal musical way that this wonderful musician and mother-aunt, could express some of her inner emotions of grief, or hurt at not being able to go, but also acceptance of doing the right thing also, because in her heart she could not leave her step-daughter. Janey's step-mum - taught all of us who empathised with her, the art of putting another's needs before your own.... part and parcel of motherly love, from a strongly well balanced, gifted musician and healthy loving woman. Her motherly dedication to Janey, inspired us all.

- Janey was able to meet some of her goals and objectives, but for me one of her MT highlights was when her older sister visited, Janey encouraged her to learn the ukulele saying "I'll help you." Or to see the expression on her face when I brought her a birthday cake their whānau could share with their 'hood' or house.

- Or perhaps it was just after Janey 'taught' her sister some ukulele chords, and I asked if they would both share their sacred mihimihi with me, as our goodbye song. They had to look at each other because they had not done this since her accident; this is them speaking their life force and ancestors aloud; and in preparation for Janey perhaps re-joining her Marae and School Community and Kapa Haka group soon. They immediately turned to face each other, smiling and holding onto each other - and spoke aloud the sacred words of belonging - to whenua, to tangata and to Atua.

Tihei mauri ora! 


\begin{tabular}{|c|c|c|c|}
\hline $\begin{array}{l}\text { \#29 Use of bubbles } \\
\text { o support breathing } \\
\text { exercises for Janey } \\
\text { During session } \\
\text { stepmum shares } \\
\text { that her nephew } \\
\text { who was a } \\
\text { "talented musician, } \\
\text { songwriter, singer } \\
\text { has committed } \\
\text { suicide." Janey is } \\
\text { very sad, but } \\
\text { expresses that as } \\
\text { her Dad has already } \\
\text { gone to The Tangi, } \\
\text { she doesn't want } \\
\text { her stepmum to } \\
\text { also leave... (\& go to } \\
\text { tangi). They share } \\
\text { his story and show } \\
\text { youtube videos he } \\
\text { made of his music. }\end{array}$ & $\begin{array}{l}\text { MT with play } \\
\text { but quickly } \\
\text { became } \\
\text { about singing } \\
\text { waiata and } \\
\text { karakia. }\end{array}$ & $\begin{array}{l}\text { MT to support } \\
\text { family/whānau } \\
\text { during time of } \\
\text { grief \& } \\
\text { bereavement. } \\
\text { Share life } \\
\text { stories of } \\
\text { deceased } \\
\text { whānau. }\end{array}$ & $\begin{array}{l}\text { I am very } \\
\text { shocked... } \\
\text { conscious } \\
\text { of my } \\
\text { own grief } \\
\text { of a } \\
\text { young } \\
\text { boy so } \\
\text { beloved } \\
\text { in my } \\
\text { hometown who also } \\
\text { took his own life last } \\
\text { night. I understand } \\
\text { their sorrow. }\end{array}$ \\
\hline $\begin{array}{l}\text { \#30 Stepmum is clearly in a } \\
\text { quandary and wishes to be at } \\
\text { tangi but is clearly torn } \\
\text { between staying to support } \\
\text { Janey or going to see her } \\
\text { nephew before his burial. } \\
\text { Janey is very vocal about her } \\
\text { Stepmum ...."they have Dad \& } \\
\text { Koro and everyone down } \\
\text { there, I don't have } \\
\text { anyone... you can't } \\
\text { go!" }\end{array}$ & $\begin{array}{l}\text { Complexities } \\
\text { abound for } \\
\text { this Whānau } \\
\text { at this } \\
\text { bereavement. }\end{array}$ & $\begin{array}{l}\text { MT for } \\
\text { comfort and } \\
\text { support } \\
\quad \text { durin } \\
\text { g sudden } \\
\text { bereavement. }\end{array}$ & $\begin{array}{l}\text { Sharing stories, } \\
\text { songs that remind } \\
\text { of this beloved } \\
\text { young man... then } \\
\text { viewing his } \\
\text { videos, soothes all } \\
\text { of us. }\end{array}$ \\
\hline
\end{tabular}

Figure 7. Example of the flow of music therapy from energising a client, into providing a pastoral care and psychotherapeutic music experience during a Client's Bereavement.

\subsection{Sudden Endings \& Student IIIness}

Unfortunately, I became ill with pneumonia - as a direct result of trying to prevent illness by submitting for the first time in my life, to the facility's kind service of the free flu-injection for staff. By the time I returned, Janey and her whānau were departing for home! Good news. We were all excited and relieved for them. It was an honour to have spent some small time with Janey and her Whānau.

The FWCMT approach contextualises the client within their family-whānau and community and cultural heritage. It is not afraid to advocate for the musicking identity, revealed within the sacred space of truthful, meaningful connection through music 
making sessions. It seems to underpin all MT approaches, and is already embedded therein, because it is about collaborating with the client and his/her family-whānau, and the interdisciplinary team around them - in order to build capacity within the family-whānau unit, by supporting their journey alongside their loved one - the client. We leave the last word to Janey's parents who had this to say about music therapy after their first two sessions:

\#8"It was relaxing and enjoyable, so different from usual therapy sessions!" 


\section{CHAPTER 6: DISCUSSION}

What did FWCMT look like on my student music therapy clinical placement? I came from a client centred philosophy, Creative Music Therapy and CoMTh approach... the Community Music Therapy approach seemed to presuppose family-whānau centred music therapy practice. Thus I found that MT approaches overlapped when this was needed as I was responding to whatever presentation was shared by the client, so that the sessions were fluid and was a 'movement' - never static. Sometimes a client asked me to stay even though they seemed tired and sleepy... or if the client seemed agitated and exhausted after a poor sleep during the night before. At these times I would use a voice only technique in a waiata/song/or pese improvising melodies without lyrics, or if asked, a favourite song from previous sessions which became almost like a lullaby to sing a client to sleep and their much needed rest.

Themes overlapped...e.g. spirituality is a supreme theme in PASIFIKA wellbeing and synonymous with whānau. The tradition I grew up with gives me assurance that this 'spirituality' incorporating a person's wairua and their mauri - is ancient, and is the theme which connects all humanity, whēnua, cosmos.

These "surprise" musical experiences, seemed to be the junction between Community Music (CoM), and Community Music Therapy (CoMT), which ClementsCortez and Pearson (2014), write of in their research asking - "when does CoMT overlap and cross over from being a therapeutic practice to being a community practice?" They also acknowledge that whilst the lines between these two approaches to music therapy do seem blurred, or indistinguishable, - the difference is that the MT can frame community music initiatives to place the emphasis on the client-centred growth and wellness, (Clements-Cortez and Pearson, 2014: 95). Perhaps most of all as they insist, in the eyes of a client or (whānau), who may be experiencing feelings of disempowerment - for them to experience an institutional community who step out of their normal clinical and ontological roles to join clients as they play music, sing, laugh and clap can be empowering. Clements-Cortez and Pearson (2014), delineate that by doing so, staff "subvert hierarchical" roles, and become more "human or approachable." The majority of staff, welcomed MT warmly and became my own supportive "institutional whānau." But there were always going to be moments of difficulty with those who were not familiar with music as therapy, and its multi-modal 
functionality, meaning that MT often engages instantly and cross culturally. It was the client engaging with their innermusic and not just me personally, is how I perceived the work. I was also surprised at discovering the responsibility of being an "advocate" for a client or family-whānau, as a health professional role that music therapists can have. Sometimes I felt as powerless as the client might seem. I had not expected music therapy to play such an important advocacy role - for the 'real person' encountered within the musicking space. I exhausted myself by verbally challenging the negative clinical descriptions of one psychologists regarding "Mrs L (Brenda), as well as "Howard." I felt strongly motivated to go over and beyond what was expected of an SMT, in order to support their life quality - and perhaps to help this clinician to "see the real person encountered within the music therapy session."

I also found myself instinctively, (perhaps nervously), falling back on both the Creative Music Therapy approach, which uses music structure in creative improvisation, (Nordoff \& Robbins, 1977), combined with the multi-sensory method from the OrffSchulwerk programme. These theoretical approaches; or hymns and songs previously chosen by the client or whānau e.g. the waiata "Pokarekare Ana," "Hoki Mai," "Tutirimai," "E Hāra I Te Mea," "Hine E" and "E Papa," or "In The Jungle," "Kumbaya," or "Let's /Don't Worry My Dear Brothers/Sisters," and "How Great thou Art/Whakaria Mai" almost like a comfort blanket, whenever I felt less sure of myself. Yet, although of Māori ancestry, I did wonder if this was helpful practice for the participants? Or was it more helpful for me?

I took comfort from the participants, staff and whānau's obvious enjoyment of these waiata, but I did begin to become mindfully aware seeming to slipinto somethingmore-comfortable, and would stop and refocus on the present - and trust my musical ability in order to be present to the client and to "trust the musical space" as we had been trained.

- To learn to wait in the silences, rather than anxiously fill in for the clients - the spaces, as often my performance background had. In music therapy, the silence and stillness space - were as important as singing or dancing... 


\subsection{Containment and Holding}

It took me many weeks of experience and MT supervision on site, and in discussion before I was finally comfortable to wholly trust the silence. That listening and empathising non-verbally, whilst observing a client's facial expressions, or limbs, toes, fingers, another crucial and dynamic concept of MT support. Then to move into the above example of a simple way to support and hold a client's emotion, whether it was tears of sadness, or angry outbursts - using my vocal training to express diverse emotions in response to what, how, why, and when a music therapy participant, or visiting family-whānau, or staff member offered any musical expressions. And to endeavour to reflect back to the client what I perceived they had tried to communicate.

Honouring this "space" by sustaining the silence, and waiting - could sometimes be misunderstood by whānau, or staff. As an SMT, I did not always manage the therapeutic-space well, or to ensure an uninterrupted session. On two occasions a wheelchair-bound client, was "hurt" by a bureau staff (outside agency) member new to the group, taking an instrument out of her hand saying "I'll show you/play it like this," or "hold it like this," before I could prevent this. I was responsible for care and safety during the MT session - and I had failed to meet the criteria of "client safety." I hoped that as I progressed in the field of music therapy, that I would develop important skills and confidence to "manage this space" to ensure safety of the client, and that above all else that the client's need, is the priority. Music therapy sessions is a safe space for clients to express their inner self in musicking, or verbally as a result of their music making, and any verbal offerings from this sharing. I was mindful that client's "behaviour issues" can be important expressions that pinpoint insights into the client's innermost thoughts and feelings - e.g. of safety, (or not feeling safe), or trust (or lack of).

\subsection{Further Music Therapy Study}

More research needs to be carried out on the FWCMT approach with this TBI population. As seen in the previous examples, there was some evidence of music therapy having a positive contribution towards client and their whānau in facilitating a meaningful encounter between them and care staff. The structure of music - rhythm (duration, beat), tempo, melody, timbre, and harmony, supports the musical meeting 
between client and their family-whānau, during any awkward, difficult, worrying or painful moment.

- I remembered 'Howard' singing his hello song with his wife, and children and visiting close friend. This simple hello-song, which he communicated in the beginning of our MT sessions, was a song from his youth, might have become intertwined with his deep yearning to return home, his sadness at being parted from his beloved wife, children and his chaplaincy mahi, his home town.

- Māori and Pacific Island Aotearoa New Zealand, clients in this study, openly spoke of or communicated that their whānau were associated with the songs, or the process of musicking, (which usually included dance). It reminded me that Māori and Polynesian Whānau gather in and with music, and are always connected through popular pese, siva, as well as through sacred hymns or waiata that is sometimes even composed especially for them, their whānau, or whēnua.

- The singing of ethnic or popular music to enhance family-whānau gatherings, and the elders presence invariably bring into the experience the waiata, the pese and the siva, kanikani. This upbringing ensured a lifelong musicassociation with whānau, and may partially explain the deep emotional yearning that music seemed to stir in Māori and PASIFIKA Kiwi clients and their whānau on my placement.

The challenge for this SMT on placement, was to be responsive to this population's well-toned rhythmic pulse embodied within clients and their whānau that is so pertinent for their wellbeing, as well as the musical creations they could express in the sessions.

- Should whānau realise this significant role that is theirs for the taking - of having a healing influence in the rehabilitation journey of their loved one, would they really continue to distance themselves into a 'room next door,' as experienced by Robinson, (2015)?

- My understanding of clinical work, and interdisciplinary relationships with care staff, therapists and whānau, has grown immensely. I hope that the facility, and 
all who welcomed music therapy so warmly, were just as informed about the multifaceted role that music therapy can play in the field of rehabilitation.

Every whānau who experienced an MT session expressed surprise, and once whānau understanding of the concepts of MT were realised, once they witnessed a transformation of the client through the MT session - they too became galvanised into becoming the helpers, advocates and even instigators of music therapy for their loved one.

\subsection{Conclusion}

\section{3(i) Cultural Influences in Aotearoa, PASIFIKA people and MT?}

These recollections of my upbringing are my own. These findings or any polarising personal views, and thoughts from this mahi are my own SMT learning and discoveries; and should not have any negative impact upon the facility, staff, or my own place of academic learning, who have only supported me throughout, to be true to myself. No offence is intended! They are shared because they have been recalled, revealed, challenged and teased out of my wairua during the course of studying music therapy - only to find that I was my first own "client" and in the hope that my journey may be useful to another SMT or anyone who is interested or identifies with the culture of PASIFIKA peoples. Although, I take leave here to reiterate the 1980 s catchcry of Wally Hirsch's Human Rights Commissioner Team (which they passed onto youth like myself) - that biculturalism must be honoured, and paramount before we can truly address multiculturalism in our Homeland. I believe this strongly still.

Be that as it may, The FWCMT approach, is a good place to continue to build upon previous literature towards an MT programme that seeks to deepen support for Māori, and PASIFIKA health. Although I had a family-whānau orientation, from the outset of my placement, I had not realised that there was such a gap in our health care for people with a TBI, who find clinical environments difficult to navigate.

The field of music therapy pertaining to this population is still relatively new in New Zealand, and yet art and music is the staple 'food' of PASIFIKA children whether in the village fale in Savai'i; or in suburbia Invercargill, Christchurch, , Wellington, Waikato, Auckland or Northland. There is music during a birth to welcome the baby and comfort the mother, music surrounds the child, with village celebrations, and into young 
adulthood with sporting songs during kerikiti (cricket), or tatau or pe'a or the malofie of the matai (Samoan ceremonies of tattooing), or as I experienced, with lifesaving fofō - let alone the church music and daily prayer services within the home fale.

Should the client's immediate whānau not engage in music (which is rare), I have never been in a village that has no musicking, or dancing - perhaps music therapy that is whānau centred, would be a welcome and enjoyable therapy to help comfort, inform, advise and enable Maori and PASIFIKA - all peoples to have a co-creating, music making role, in an interdisciplinary hospital or clinic setting?

The continued close working relationship between Aotearoa New Zealand and Pacific Island nations such as Samoa, can contextualise people, their aiga/whānau, to perhaps explore pertinent ways to decrease and halt our domestic violence statistics in both countries? We Samoans can show our appreciation for Kiwi hospitality, and aid by cleaning up our own back yard. Yet, due to my relationship with a young mum who was so severely disabled now, due to her husband's physical violent attacks upon her Tapu Tangata, her personhood, I realised that music therapy must already be encountering the 'victims' and 'survivors' in hospital, clinic or the school and community environment - for decades. It gave me hope that perhaps this form of FWCMT is already available as a support for many "survivors" - to flourish and to "fly free." The data showed that it seemed true of the eight people, their loved ones, and staff whose music therapy participation during our time together, have been mined, sifted, examined and agonised over. I pray that I honour here the mahi that we all shared together.

- Perhaps this whānau centred music therapy approach may contribute towards yielding sustainable results to foster dialogue, emotional expression and mental health and wellbeing. It works alongside, and for communities, (Stige, 2000), towards positive interpersonal interaction within the individual; within the aiga/whānau - and within the community they reside.

Thus it would be helpful to welcome more Māori and PASIFIKA musicians to the profession of music therapy and the Master of Music Therapy Degree, at the New Zealand School of Music, Victoria University, Wellington. But I would urge them to be rigorously disciplined and musically prepared, and of more optimum health than I was. 
These were intimidating challenges for me on placement, and continues to be so. Leaving my whānau to travel to Wellington, in pursuit of music therapy was a shock to my whānau and I - a challenge around my own personal belief that whānau have to come first, was having to leave my own then. It was almost too much to bear after the painful passing of five beloved souls who have supported my musicking for 20-30 years, before I could bring this new learning to their bedside.

Thus, further challenged by the questions raised within my own brain during this research on the complexities and boundaries around collaborative music therapy that is family-whānau centred, I wondered:

- Would it be helpful for client and family-whānau, if music therapy were available as part of health care during the acute stages of hospital admittance with TBI?

- Which led to another question from the data regarding cultural diversity of clients on my placement and the way music therapy was able to enhance their wellbeing and non-musical goals: if boundaries are cross-cultural, how can other therapists gain access to this cultural knowledge, or be informed of cultural norms and taboos that they have not been brought up with, when a situation arises?

Finally - if a person approaches another, with respect, care and aroha, and yet have little cultural knowledge of the other, should this not be able to transcend and transform the music therapy musiking co-creating, sharing experience? When all else fails, aroha and respect is enough. Yet, there were answers also to implicit questions of this approach, which have changed my own attitude towards working with clients and their family-whānau. For example, I have been surprised by the communicative tool that is music therapy which can seamlessly address both individual client goals and objectives whilst in a group setting, and vice versa. Music therapy is by its multimodal form - creative, inclusive, playful, soothing whilst motivating, and was continually challenging to both client, their family-whānau, therapy teams, care staff and to myself.

Music therapy sessions are a safe and sacred space and place - as wide, long, and expansive as you need, or as tiny and intimate as you wish for - just as Carolyn Kenny's 
insightful, global māhi advocates: a field of playing, laughing, crying, giggling, serious, sorrowful, angry or anxious, surprised and happy Beings; a place where every facet of a person's wairua, hinengāro, tinana, and that of their whānau, is welcome, respected and honoured. It is a privilege to meet you here. 


\section{REFERENCES}

Abiru, M, \& Thaut, M H. (2009). Rhythmic Auditory Stimulation In Rehabilitation of

Movement Disorders: A Review of Current Research. Music Perception Journal.

University of California, Volume 27, Issue 4. pp 263269.

ABI Rehabilitation, (2013). Auckland. http://www.abi-rehab.co.nz/abi-

rehabilitationhttp://www.abi-rehab.co.nz/abi-rehabilitation-

newzealandour-philosophy/new zealandour-philosophy/

Aigen, K. (2005). Music-centered music therapy. Gilsum, NH: Barcelona Publishers.

Aldridge, D. (1997). Music Therapy in Palliative Care, New Voices. London: Jessica Kingsley.

American Music Therapy Association. (2016). AMTA standards of practice.

Retrieved from http://www.musictherapy.org/

Angas, G, F. (1866) Polynesia; A popular description of the physical features,

Inhabitants' natural history, and productions of the islands of the Pacific. With an Account of their discovery, and the progress of civilisation and Christianity amongst Them. Society for Promoting Christian Knowledge, London.

Part of: Tidal Pools: Digitized Texts from Oceania for Samoan andPacificStudies

Ansdell, G.. (1995). Music for Life. Aspects of Creative Music Therapy with Adult Clients. London: Jessica Kingsley Publishers.

Ansdell, G., Davidson, J., Magee, W. L., Meehan, J. \& Proctor, S. (2010). From "This $F^{* * *}$ ing life" to "that's better"... in four minutes: an interdisciplinary study of music therapy's "present moments" and their potential for affect modulation. Nordic Journal of Music Therapy, 19:1, 3-28 
Ansdell, G., M, John. (2010). Exploring Users' Evidence for the Effectiveness.

Online Sage Settings. Victoria University database, Wellington, NZ.

Ayson, Carolyn, May, (2007). Child-Parent Wellbeing in a Paediatric Ward: The Role of Music Therapy in Supporting Children And Their Parents Facing The Challenge Of Hospitalisation. Unpublished Masters' Thesis, Massey \&Victoria Universities, Wellington NZ.

Baker, F., and Tamplin, J., (2006). Music Therapy Methods in Neurorehabilitation, $A$ Clinician's Manual. London: Jessica Kingsley Publications

Barnes, S., S, Green, R, C. (2008). From Tongan Meeting House to Samoan Chapel: The Journal of Pacific History. 43:1. DOI: 10.1080/00223340802054594.22-49 To link to this article:http://dx.doi.org/10.1080/00223340802054594

Barret, R, D., McLellan, T, L., McKinley, A, PLoS One 8.10 (2013). "Self versus Family Ratings of the Frontal Systems Behaviour Scale and Measured Executive Functions: Adult Outcomes following Childhood Traumatic Brain Injury" Search.proquest.com.helicon.vuw.ac.nz (Victoria University library database).

Best Practice Medical Magazine, August, (2011).

www.bpac.org.nz/BPJ/2011/august/whanu ora.aspx

Boon, A., (2012), Excellence through patient centred care: Health Quality and Safety Commission, Bay of Plenty District Health Board. New Zealand.

Borzcon, R., (2004). Music Therapy: A Fieldwork Primer. Gilsum NH: Barcelona Publishers. 11-18.

Bradt J, Magee WL, Dileo C, Wheeler BL, McGilloway E. (2010). Music therapy for acquired brain injury. Cochrane Database of Systematic Reviews, Issue 7. Art. No.: CD006787. DOI: 10.1002/14651858.CD006787.pub2.

Bunt, L. (1994). Music Therapy An Art Beyond Words. Routledge, London. 
Bunt, L. \& Hoskyns, S. (Eds.) (2002). The Handbook of Music Therapy. London:

Routledge Taylor \& Francis Group, U.K.

Braun, V, \& Clarke, V. (2006). Using Thematic Analysis in Psychology. Qualitative Research in Psychology, 3(2), 77-101.

Bright, R, (1986). Grieving. St Louis: MMB Publications.

Bronfenbrenner, U. (1994). Ecological models of human development. In International Encyclopedia of Education, Vol. 3, $2^{\text {nd }}$. Ed. Oxford: Elsevier. Reprinted in: Gauvain, $M$. \& Cole, M. (Eds.), Readings on the development of children, $2^{\text {nd }}$ Ed. (1993, pp. 37- 43). NY: Freeman

Bruscia, K, E. (Ed.) (1991). Case Studies In Music Therapy. Gilsum NH: Barcelona Publishers. 5

Bruscia, K, E. (2005). Designing Qualitative Research. In Wheeler, B. (Ed.), Music Therapy Research (Second Ed.). Gilsum NH: Barcelona Publishers.

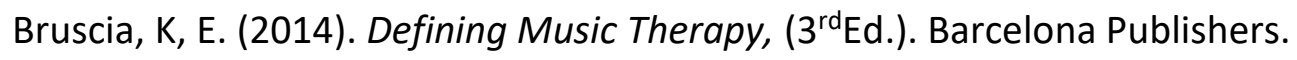

Clements-Cortes, A, \& Pearson, S. (2014). Discovering Community Music Therapy in practice: Case Reports from two Ontario hospitals. International Journal of Community Music, 7 (1), 93-111.

Dennis, P. \& Rickson, D. J. (2015). The Leader of the Band: A Case Story of Community Music Therapy on a Hospital Ward for People Who Have Dementia.

Voices: A World Forum for Music Therapy, [S.I.], v. 14, n. 1, feb. 2014. ISSN

1504-1611.https://voices.no/index.php/voices/article/view/728/633> doi:10.15845/voices.v14i1.7.

Dileo, C. \& Loewy, J. (Eds.) (2005). Music Therapy at the End of Life. Cherry Hill NJ Jeffrey Books. 
Duranti, A., (1992), Language and Bodies in Social Space: Samoan Social Greetings. Los Angeles, University of California. Journal of American Anthropological Association. Online Sage Publications, Victoria University online database, Wellington, NZ. 657691.

Durham, C. (2002). Chapter 7 in L. Bunt \& S. Hoskyns (Eds.) The Handbook of Music Therapy. London: Routledge Taylor \& Francis Group, U.K. p. 115-131.

Durie, M.H. (1985). A Maori Perspective of Health. Journal of Social Science and Medicine, 483-486.

Farber, Stuart, J., Egnew, Thomas, R., Herman-Bertsch, Janet, L., Taylor, Thomas, R., Guldin, Gregory, E. (2003). Issues in end-of-life care: patient, caregiver, and clinician perceptions. Journal of palliative medicine, February, Vol. 6.(1), pp.19-31.

Glass, G. V. (1976). Primary, Secondary, and Meta-Analysis of Research. Educational Researcher, 5(10), 3-8.

Hannon, M. J., Sherlock, M., Thompson, C.J. (2011). Pituitary dysfunction following traumatic brain injury or subarachnoid, haemorrhage - In "Endocrine Management in the Intensive Care Unit." Best Practice \& Research Clinical Endocrinology \& Metabolism. 25(5), $783-798$

Heaton, J. (2008). Reworking qualitative data. London: Sage Publications Ltd.

Higginson, F, L. (1992) The Samoan Fale, UNESCO Office for the Pacific States, Report printed under UNESCO-AGFUND Regional Project. Development of Educational Facilities in Asia and the Pacific, Thailand. Online database, Victoria University, Wellington, New Zealand, 11-79.

Hilliard, Russell, E. (2003), The Effects of Music Therapy on the Quality and Length of Life of People Diagnosed with Terminal Cancer. Florida, American Music Therapy Association, 113-137. 
Hitchen, H; Magee, Wendy L; Soeterik (2010). Music Therapy in the treatment of patients with neuro-behavioural disorders stemming from acquired brain injury. Nordic Journal of Music Therapy,Taylor \& Francis Online Vol 19; Issue 1; p. 63-78, Great Britain, UK.

Kennelly, J. (2006) In F. Baker \& J. Tamplin, (2006). Music Therapy Methods in Neurorehabilitation, A Clinician's Manual. London: Jessica Kingsley Publications. Chapter 6 p. 219-233.

Kenny, C. (1989, 2006). The Field of Play: A Guide for the Theory and Practice of Music Therapy. Ridgeview Publishing Co.

Kenny, C. (1998). Embracing Complexity: The Creation of a Comprehensive Research Culture in Music Therapy. Journal of Music Therapy, XXXV (3). 201-217.

Kenny, C. (2014). The Field of Play: Ecology of Being in Music Therapy. Voices Online Forum, Vol 14, No. 1.

Lagolago, W., Theadom, A., Fairbairn-Dunlop, P., Ameratunga, S, Dowell, A., McPherson, K, M., Te Ao, B., Starkey, N, J.

Feigin, V L. (2015). Traumatic brain injury within Pacific people of New Zealand. Bionic Research Group. The New Zealand Medical Journal, Volume 128, Number 1412.

Lammers, M, (2012). Toward Cultural Safety, experiences of a non-Māori working with Māori, Journal of NZ Association of Occupational Therapists. Vol 33, No. 5.9.

Lee, J. J., Segar, D.J., Asaad, W. F. (2014). Comprehensive Assessment of Isolated Traumatic Subarachnoid Hemorrhage. Journal of neurotrauma. 31(7), 35 -609. http://dx.doi.org/10.1089/neu.2013.3152. 
Leman M, Moelants D, Varewyck M, Styns F, van Noorden L, et al. (2013). Activating And Relaxing Music Entrains the Speed of Beat Synchronized Walking. PLoS ONE 8(7):e67932.doi:10.1371/journal.pone.0067932

Lupe, K. (2013), Pacific INDIGENOUS Well-being, Wise body Singing Heart. In M.N. Agee, T. McIntosh, P. Culbertson, C. 'Ofa Makasiala, (Eds.), Pacific Identities and Well Being, Cross Cultural Perspectives. pp 228-239 (Chapter 14).

Malloch, S., Shoemark, H., Rudi, C., Newnham, C. Paul, C. Prior, M. Coward, S \& Burnham, D., (2012). Music Therapy With Hospitalized Infants - The Art and Science of Communicative Musicality. Infant Mental Health Journal, Vol.

33(4), 386-399.(2012), wileyonlinelibrary.com. DOI: 10.1002/imhj.21346.

Maratos, A. Gold, C. Wang, X. Crawford, M. (2008). Music therapy for depression, The Cochrane Library, Wiley Online Library. DOI:10.1002/14651858.CD004517.pub2

McWilliams, N, (2004). Psychoanalytic Psychotherapy: A Practitioner's Guide. New York, The Guilford Press. 131-162.

Molyneux, Claire, (2015). Supervision discussion during SMT placement.

NIH Consensus Development Conference on Rehabilitation of Persons With Traumatic Brain Injury. (1998). National Institutes of Health Rehabilitation of Persons with Traumatic Brain Injury.

Nordoff, P, Robbins, C. (1977). Creative music therapy Nordoff P. \& Robbins C. Creative music therapy. New York, NZ: John Day.

Odell-Miller, H. (1995). Why provide music therapy in the community for adults with mental health problems? British Journal of Music Therapy. 
O’Kelly, J., Magee, W, L, (2012), Music Therapy with disorders of consciousness and neuroscience: the need for dialogue. London, Nordic Journal of Music Therapy. Vol. 22:2,93-106,DOI:10.1080/08098131.2012.709269, http://dx.doi.org/10.1080/0809131.2012.70269

Oldfield, A., and Flower, C., (eds. 2008). Music Therapy with Children and Their Families. London, Jessica Kingsley Publishers. 121-140.

Pavlicevic, M., \& Ansdell, G. (2004). Community music therapy. London: Jessica Kingsley Publishers.

Pearsall, J, and Trumble, B, $2^{\text {nd }}$ Ed., (1996). The Oxford English Reference Dictionary. New York, Oxford University Press.

Phillips-Silver, J. (2009). On the Meaning of Movement in Music, Development And the Brain, Contemporary Music Review. 28:3, 293-314,

DOI: $10.1080 / 07494460903404394$

To link to this article: http://dx.doi.org/10.1080/07494460903404394

Pragad, Sidhartha, (2014). What Is the Role of A Student Music Therapist in Community Music Setting? Wellington, Massey University, Victoria University, Press.

Priestly, M. (1975). Music therapy in action. London: Constable.

Priestly, M. (1981). Transference and countertransference in music therapy.

Priestly, M. (1994). Essays on analytical music therapy. Phoenixville, PA: Barcelona Publishers.

Pulotu, E, F, K. (1982). Pacific Mental Health Services and the workforce: Moving the Blueprint. Wellington, Ministry of Health. 
Rickson, D., McFerran, Katrina, Skewes. (2014). Creating Music Cultures in the Schools: A Perspective from Community Music Therapy. U.S.A, Barcelona Publishers. 22-23.

Rogers, C.R. (1951). Client-centered therapy: Its current practice, implications, and theory. London, England: Constable.

Rolvsjord, R. (2013). Music therapy in everyday life, with "the organ as the third therapist."

Centre for Music and Health Publications Series, 6.

Ruud, E. (1998). Music therapy: Improvisation, communication, and culture. Gilsum, NH: Barcelona Publishers.

Ruud, E. (2010). Music Therapy: A Perspective from the Humanities. Gilsum, Barcelona Publishers.

Seuili, B, Malaela, S. (2013). Counselling Psychology, From a Samoan perspective. NZ, University of Waikato.

Shoemark, H. (1996). Family-centred early intervention: Music Therapy in the PLaygroup Program. Australian Journal of Music Therapy. Vol. 7: Issue 1996. Small, C. (1998). Musicking; The meanings of performing and listening. Hanover, Germany: University Press of New England.

Schwandt, T. A. (3 ${ }^{\text {rd }}$ Ed.) (2007). The SAGE dictionary of qualitative inquiry. Los Angeles: SAGE Publications. 
Statistics New Zealand (2015), New Zealand Police recorded crime and apprehension tables.

http://nzdotstat.stats.govt.nz/wbos/index.aspx?DataSetCode=TABLECODE7407.

Stern, D. (1985) The Interpersonal World of the Infant: A View from Psychoanalysis and Developmental Psychology. London: Academic Press.

Stige, B. (2000). The relentless roots of community music therapy. Voices: A World Forum

for Music Therapy, 2(3).

Stige, B. (2014). Community music therapy and the process of learning about and Struggling

For openness. International Journal of Community Music, 7 (1), 47-55.

Stige, B; Ansdell, G; Elefant, C; Pavlicevic, M, (2010). Where Music Helps:Community Music Therapy in Action \& Reflecton. Farnham: Ashgate Publishing Limited, UK.

Taumoefolau, M. (2013). Respect, Solidarity, and Resilience in Pacific World View, A Counselling Perspective. In M.N. Agee, , T. Mclntosh, P. Culbertson, C. Makasiala, (Eds.), Pacific Identities and Well Being, Cross Cultural Perspectives (Chapter 7).

Thaut, M, H., McIntosh., G.C., Rice, R, R., et al, (1996). Rhythmic auditory stimulation in gait training for Parkinson's disease patients. Movement disorders, 11 (2), 193-200.

Thaut, Michael, H. (2005). Rhythm, Music and The Brain, Scientific Foundations and Clinical Applications, Scientific Foundations and Clinical Applications. New York, Routledge, 128131. 
Thaut, M., McIntosh, G. (2010). How Music Helps to Heal the Injured Brain, Therapeutic Use of Crescendos Thanks to Advances in Brain Science. Cerebrum, The DNZ Foundation. dna.org

Wheeler, Barbara, (2005). Music Therapy Research. Gilsum NH: Barcelona Publishers Wheeler, B, L., \& Kenny, C. (2005). Principles of qualitative research. In B.L. Wheeler (Ed.) Music therapy research, (2 ${ }^{\text {nd }}$ Ed., pp.59-71). Gilsum, NH: Barcelona Publishers.

Wilson, S, L, (2010). Le Tofi Ne'I Vale Tuulima, Perceptions of Samoan Students, Teachers and Parents on the Place of The Samoan Language in New Zealand today. Victoria University Thesis, Wellington, NZ.

Winnicott, D.W. (1965). The Family and Individual Development. London: Tavistock.

Wolf, D, E, (2000). Group Music Therapy Model in Acute Mental Health Care; Meeting the Demands of Effectiveness and Efficiency.

World Health Organization, (2002). Towards a common language for functioning, Disability and health: ICF the International Classification of Functioning, Disability and Health. http://www.who.int/classifications/icf/training/icfbeginnersguide.pdf 


\section{Appendix 1.}

The following are a few of the Māori words which I learnt in waiata and kapa haka through weekly classes in St John's the Evangelist Primary School or on Whai Ora marae, Otara.

Te Reo Māori ngā kupu

\begin{tabular}{|l|l|}
\hline Atua, lo & God, Supreme Creator \\
\hline Arohā & love \\
\hline Karakia & sacred chant, prayer \\
\hline Kaumātua & $\begin{array}{l}\text { Māori Elders (who often advise on a } \\
\text { formal platform in the community) }\end{array}$ \\
\hline Koro & Grandfather, elderly man \\
\hline Kuia & Grandmother, female elder, \\
\hline Mahi & Work \\
\hline Mātua & Māori elder (male) \\
\hline Marāe & Sacred Ancestral Ceremonial Whare \\
\hline Mauri & Life force, vital essence \\
\hline Tautoko & Support, prop up, advocate for \\
\hline Ti Tiriti O Waitangi & The Treaty of Waitangi, 1840. \\
\hline Waiatā & Song, sing \\
\hline Wairua & Lanit, soul of a person \\
\hline Whānau & Hharena \\
\hline
\end{tabular}


The following Samoan upu-kupu-words are based on my own 'immigrant's' knowledge of colloquial Samoan spoken - Samoa, and used in the family-

whānau, aiga in the Aotearoa NZ context - this land of my Parents' migration.

\section{Gagana fa'a Samoa}

\begin{tabular}{|c|c|}
\hline Atua, Ali'i & lo, God, Supreme Creator of all Chiefs, \\
\hline Afakasi & Person of Samoan and European parents \\
\hline Aiga & Family-whānau, whānau \\
\hline Ali'i & Village Chief \\
\hline Alofa & Love, aroha \\
\hline Apia & Capital of Samoa \\
\hline Aso Anomua & Ancient times \\
\hline Aulotu & Parish community \\
\hline Autalavou & Youth group \\
\hline Ekālesia Katoliko & Ecclesiastical Catholic church \\
\hline Fa'aSamoa & $\begin{array}{l}\text { In the manner of Samoans, Samoan way of life and } \\
\text { culture }\end{array}$ \\
\hline Falealupo & Ancient landing place of The Ancestors \\
\hline $\begin{array}{l}\text { Outcropping of volcanic rocks is here - } \\
\text { Fafa, pulotu }\end{array}$ & $\begin{array}{l}\text { Ancient sacred spiritual place where the spirits } \\
\text { of the dead, depart this world. }\end{array}$ \\
\hline Fale & Whare, house \\
\hline Fale tele & $\begin{array}{l}\text { village house of ceremony (in ancient time), as well } \\
\text { as of hospitality for visitors }\end{array}$ \\
\hline Fale afolau & $\begin{array}{l}\text { Centuries later modified Tongan model of the } \\
\text { Fale Tele }\end{array}$ \\
\hline Fānau & children, offspring; to give birth \\
\hline Fusi & $\begin{array}{l}\text { traditional healing compress for high } \\
\text { fevers/temperature illness; to bind }\end{array}$ \\
\hline Fofo (macron on the "o") & traditional massage \\
\hline Ifoga & $\begin{array}{l}\text { the ritual apology - seeking forgiveness \& } \\
\text { justice }\end{array}$ \\
\hline Lomatua & Elder Woman, Grandmother, Kuia \\
\hline Toeiga & $\begin{array}{l}\text { The esteemed older men and women/ the } \\
\text { elders }\end{array}$ \\
\hline
\end{tabular}




\begin{tabular}{|c|c|}
\hline Mana & Divine power, God's grace \\
\hline $\begin{array}{l}\text { Matai } \\
\text { There are two orders of matai - ali'i } \\
\text { and tulafale }\end{array}$ & $\begin{array}{l}\text { Political representative of the Whānau who } \\
\text { holds a title ...Bestowed by the aiga, (tulafale) } \\
\text { custodian of land and property }\end{array}$ \\
\hline Matua & $\begin{array}{l}\text { Parent, (be) mature (but not fully ripe), adult, } \\
\text { grown-up. }\end{array}$ \\
\hline Tuaa, Tupuga & Ancestors \\
\hline Papalagi & $\begin{array}{l}\text { Palagi-European } \\
\text { When the early settlers arrived in Samoa in } \\
\text { huge vessels of sailing ships, they fired canons } \\
\text { at sighting of land (and perhaps to announce } \\
\text { their military might?).... The early people of } \\
\text { Samoa thought that "the gods are descending } \\
\text { from the heavens which are exploding" as a } \\
\text { result - papalagi or papa mai lagi }\end{array}$ \\
\hline Pese & Song, waiata \\
\hline Savai'i & "Mainland" of Samoa \\
\hline Siva & Dance \\
\hline Tamaiti, Fanau & Children, Little Ones \\
\hline $\begin{array}{l}\text { Tama } \\
\text { Teine } \\
\text { Tamaloa } \\
\text { Fafine }\end{array}$ & $\begin{array}{l}\text { Boy } \\
\text { Girl } \\
\text { Man } \\
\text { Woman }\end{array}$ \\
\hline Tapu & Holy, sacrosanct or spiritual restriction \\
\hline $\begin{array}{l}\text { Tatau } \\
\text { Sisters Tilafaiga \& Taema brought the art of } \\
\text { Samoan tattoo from Fiti, which they carried in a } \\
\text { waiata, pese, song - landing in Falealupo... } \\
\text { legend has it that the sisters fell out of their } \\
\text { canoe during the voyage. When they managed to } \\
\text { get back into their canoe - their song lyrics had } \\
\text { been altered, and instead of women being } \\
\text { tattooed, the song told of men having the } \\
\text { tattoo... }\end{array}$ & $\begin{array}{l}\text { Tattoo - 'sacred' tradition } \\
\text { The author's Ancestor is Tilafaiga, mother of } \\
\text { Nafanua - goddess of war and peace. } \\
\text { As a five-year-old child, we visited the Fafa by } \\
\text {... to the caves of the ancestral landing where } \\
\text { the tatau story, and the women's cave, as well } \\
\text { as the legend of Moso "tu-vaelua" was } \\
\text { imparted, (legend retold by mother who also } \\
\text { spoke of the meaning of "papalagi" in this } \\
\text { cave). } \\
\text { Wading in the Fafa waters on my father's shoulders as he } \\
\text { spoke this tale \& being asked "do you accept? Do you } \\
\text { trust me?" - is still a sacred, but slightly hair-raising } \\
\text { memory.Humming a tune that he sung often, Whom did } \\
\text { father learn this from? }\end{array}$ \\
\hline Tusigaigoa & $\begin{array}{l}\text { Formal gathering in collection of funds } \\
\text { \&feasting, dancing in Aotearoa, NZ. }\end{array}$ \\
\hline Upolu & $\begin{array}{l}\text { The "town" island, where the capital of Samoa, } \\
\text { Apia is situated. }\end{array}$ \\
\hline Usita'i & $\begin{array}{l}\text { Obey, obedience - synonymous with respect of } \\
\text { one's elders, the space of elders, ancestors is } \\
\text { sacred } \\
\text { "They have lived life, suffered and, they have } \\
\text { paved the way for generations to come." } \\
\text { Usita'i, usita'l, e maua ai lau malo....! The } \\
\text { Aunties used to chant }:-\end{array}$ \\
\hline
\end{tabular}




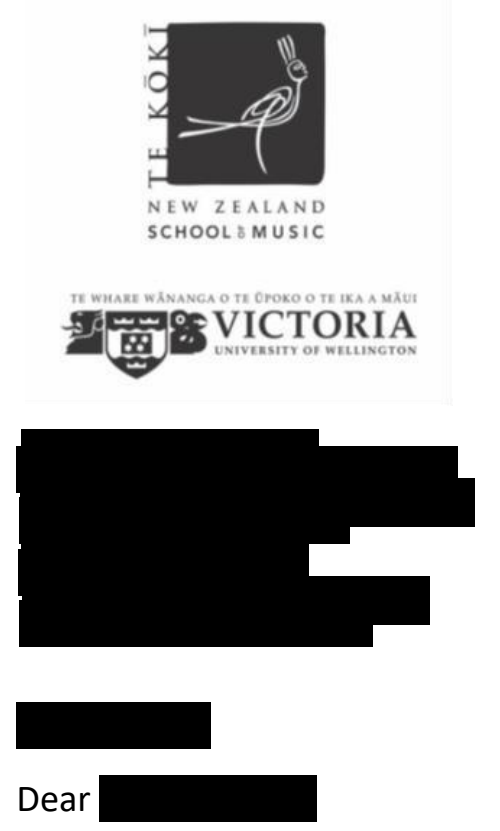

Tena Koutou Katoa

Thank you for the opportunity and privilege of accepting my student music therapist clinical placement, 2015.

As you may be aware, I am in my second year of Te Koki NZSM Masters of Music Therapy degree. As part of the programme I am required to conduct research relating to clinical music therapy work by using secondary review of data. My research question is: How was a family-centred music therapy approach demonstrated within a music therapy student's work alongside clients and their family-whānau, undergoing traumatic brain injury (TBI) or acquired brain injury (ABI) rehabilitation?

This project has been reviewed and approved by the Victoria University NZSM Postgraduate Committee, and the Victoria University Human Ethics Committee has approved music therapy student research under a template for studies using secondary review of data. I have attached a research proposal for further information about my study.

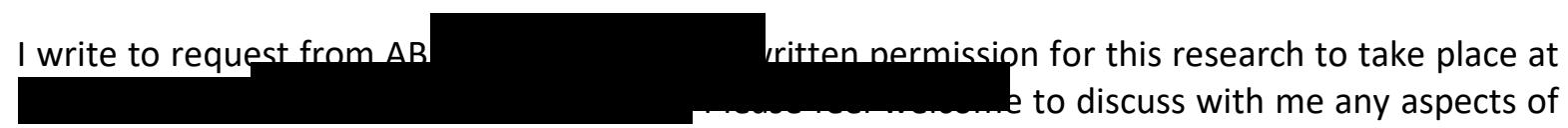

my research and/or giving permission to conduct research.

Should you agree that you have obtained sufficient information about this research and consent to give your permission, then would you please send that confirmation via email by September $14^{\text {th }}$ 2015 - as I will need your statement to proceed with my research.

Please contact me or my research supervisor Associate Professor Sarah Hoskyns, via email: sarah.hoskyns@nzsm.ac.nz or by mobile:_ should you have any concerns or questions relating to this research.

Thank You so much, and I look forward to your kind reply in the near future.

Nga mihi nui

Retts van Dam

Attachment: Research Proposal 


\section{Appendix 4 Consent Clinic form Case Vignette}

ABI Rehobilitotion New Zealand Ltd
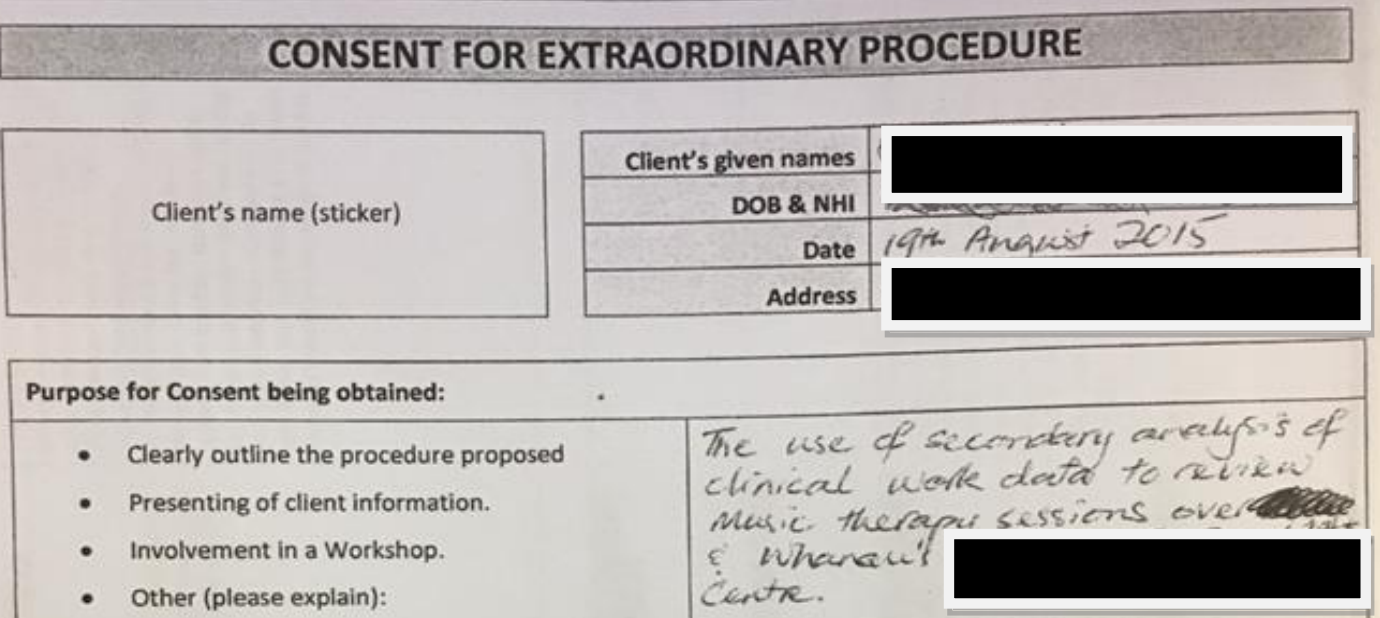

- Clearly outline the procedure proposed

- Presenting of client information.

- Involvement in a Workshop.

- Other (please explain):

The use of scempterif artely sis of clinical werk data to kivin muic: therapi sessians overabele \& Whanaci's ceatre.

Where appropriate please attach information form. Please note: There are separate consent forms for:

Where appropriate please attach information form. Please note: There are separate consent forms for:
\begin{tabular}{|l|l|l|}
\hline Informed Consent for Assessment \& & Client Consent to Casting Treatment - \\
Rehabilitation - FM220 & FM466 & \\
\hline $\begin{array}{l}\text { Patient Consent to Intrathecal Baclofen } \\
\text { Trial Dose(s) - FM447 }\end{array}$ & $\begin{array}{l}\text { Medication Self Administration Consent - } \\
\text { FM473 }\end{array}$ & $\begin{array}{l}\text { AKL Restraint Assessment \& Consent } \\
\text { Form - FM246 }\end{array}$ \\
\hline Botulinum Toxin Treatment Patient & ABI Rehab \& WINZ Permission Form - & \\
Consent - FM445 & FM453 & \\
\hline
\end{tabular}

Consent - FM445

\section{TO BE COMPLETED BY STAFF MEMBER REQUESTING CONSENT}

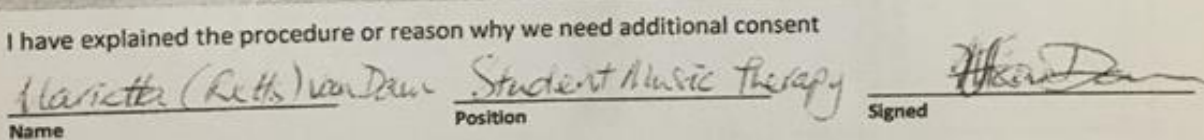

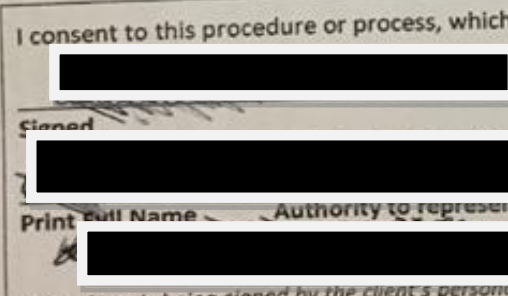

ch has been explained to me fully. If this form is being signed by the cilents personurrepresentative, ple:

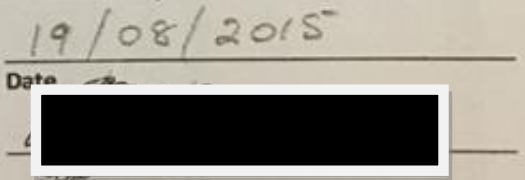

(Staff member must sight the authority)

\section{TO BE COMPLETED BY STAFF MEMBER WITNESSING CONSENT}
Authority sighted (tick)
$\square \mathbf{Y}$
D $\mathbf{N}$
Specify
type:

Name of Staff member

Date:

witnessing consent 


\section{Appendix 5. Example of initial coding after colour coding step}

\begin{tabular}{|c|c|c|c|c|}
\hline Date: Data Source & Data & Coding & Theme & Theme \\
\hline $\begin{array}{l}\# 30 \text { Mrs C notes } \\
13 / 04 / 14\end{array}$ & $\begin{array}{l}\text { I greeted Mrs C in her cultural } \\
\text { language and she replied in kind "I'm } \\
\text { well thank you }\end{array}$ & $\begin{array}{l}\text { cultural respect } \\
\text { Identity }\end{array}$ & $\begin{array}{l}\text { Cultural respect helps build } \\
\text { therapeutic } \\
\text { relationship }\end{array}$ & $\begin{array}{l}\text { Cultural respect } \\
\text { Identity Therapeutic } \\
\text { relationship }\end{array}$ \\
\hline $\begin{array}{l}\# 31 \\
13 / 04 / 15\end{array}$ & $\begin{array}{l}\text { Mrs C chose a song on ipad...relaxed } \\
\text { totally with } 2 \text { nd song. }\end{array}$ & $\begin{array}{l}\text { Enabling, empowerment } \\
\text { client choice relaxes } \\
\text { client }\end{array}$ & Enabling, empowerment & $\begin{array}{l}\text { Agency } \\
\text { Empowerment }\end{array}$ \\
\hline $\begin{array}{l}\# 32 \\
13 / 04 / 15\end{array}$ & $\begin{array}{l}\text { Then played "Sulu sulu" on guitar } \\
\text { which she moved her lips to and this } \\
\text { seemed to surprise and give pleasure } \\
\text { to her Whānau }\end{array}$ & $\begin{array}{l}\text { Client's participation } \\
\text { in music gives } \\
\text { enjoyment to both client } \\
\text { and family-whānau }\end{array}$ & $\begin{array}{l}\text { whānau witness client's } \\
\text { music participation }\end{array}$ & $\begin{array}{l}\text { whānau in session } \\
\text { Motivating effect for } \\
\text { client? Or was it her } \\
\text { choosing own music to } \\
\text { listen to? Or both? }\end{array}$ \\
\hline $\begin{array}{l}\# 34 \\
13 / 04 / 15\end{array}$ & $\begin{array}{l}\text { Cousin aid that Mrs C likes GREASE } 2 \\
\text { sound track more than Grease... But } \\
\text { Aunty said that "Mrs C really loves } \\
\text { Saturday Night Fever - and used to } \\
\text { dance a lot to John } \\
\text { Travolta..." }\end{array}$ & $\begin{array}{l}\text { Whānau in session share } \\
\text { musical history of client }\end{array}$ & Family in session & $\begin{array}{l}\text { Family in session } \\
\text { Shared musical history }\end{array}$ \\
\hline $\begin{array}{l}\# 181 \text { Mrs C's notes } \\
19 / 07 / 15\end{array}$ & $\begin{array}{l}\text { Staff made a special cake. Her Dad was } \\
\text { there, I asked him to play. He was } \\
\text { hesitant at first ... then committed to } \\
\text { playing both the ukulele \& guitar }\end{array}$ & $\begin{array}{l}\text { Being alongside the } \\
\text { meeting of client \& her } \\
\text { Dad, staff, family-whānau } \\
\text { Family-whānau in session }\end{array}$ & $\begin{array}{l}\text { Inviting \& encouraging client's } \\
\text { parent to play music } \\
\text { instrument }\end{array}$ & $\begin{array}{l}\text { Supporting family } \\
\text { interpersonal } \\
\text { relationships }\end{array}$ \\
\hline $\begin{array}{l}\# 182 \\
19 / 07 / 15\end{array}$ & $\begin{array}{l}\text { I asked him if he would prefer to make } \\
\text { eye contact with his daughter...he } \\
\text { immediately moved forward to do so } \\
\text { in front of her, calling her name and } \\
\text { singing Happy Birthday in their } \\
\text { 'mother tongue.' }\end{array}$ & $\begin{array}{l}\text { Facilitative role to } \\
\text { enhance family-whānau } \\
\text { contact through their } \\
\text { shared musical moment }\end{array}$ & $\begin{array}{l}\text { Enhancing father-daughter } \\
\text { meeting in the music by } \\
\text { enabling parent }\end{array}$ & $\begin{array}{l}\text { Supporting family- } \\
\text { whānau as they 'meet } \\
\text { in the music' }\end{array}$ \\
\hline $\begin{array}{l}\# 164 \text { BRENDA's } \\
\text { notes } \\
06 / 05 / 15\end{array}$ & $\begin{array}{l}\text { BRENDA values \& engages well when } \\
\text { her Whānau are surrounding her. } \\
\text { Daughter \& her little son played the } \\
\text { bongo whilst her husband played the } \\
\text { concertina. }\end{array}$ & $\begin{array}{l}\text { Facilitating family-whānau } \\
\text { music making with } \\
\text { spouse, daughter } \\
\text { \&grandson }\end{array}$ & $\begin{array}{l}\text { Client becomes motivated } \\
\text { \&engaged/experience } \\
\text { musicking together }\end{array}$ & $\begin{array}{l}\text { Family-whānau in } \\
\text { session }\end{array}$ \\
\hline $\begin{array}{l}\text { \#33 HESS notes } \\
02 / 09 / 15\end{array}$ & $\begin{array}{l}\text { Hess grabbed maracas playing this } \\
\text { throughout his favourite song of the } \\
\text { moment } \\
\text { "That's Amore." } \\
\text { Hess remembered all of the waiata, "E } \\
\text { Hara I Te Mea" "Hoki Mai," "Tutiria } \\
\text { Mai" and "Pokarekare Ana" - whereas } \\
\text { in the past he has not been able to } \\
\text { join in with singing these waiata. good } \\
\text { his "little girl" has how } \\
\text { been, (bringing into special kai/foods } \\
\text { that her Dad likes to eat).., }\end{array}$ & $\begin{array}{l}\text { Hess shared a story of his } \\
\text { Wife and Daughter in } \\
\text { regards to his tattoos, He } \\
\text { became emotional and } \\
\text { expressed his aroha for her, } \\
\text { and how much he missed } \\
\text { his Wife }\end{array}$ & $\begin{array}{l}\text { After breathing to relax } \\
\text { "down" from MT session, and } \\
\text { discussing how his body also } \\
\text { needs to stretch out and rest }\end{array}$ & $\begin{array}{l}\text { Client talks about his } \\
\text { tattoos \& links them to } \\
\text { his wife \& daughter. } \\
\text { client shares he misses } \\
\text { his wife. } \\
\text { Client shares past } \\
\text { experience about his } \\
\text { tattoos when a youth... }\end{array}$ \\
\hline
\end{tabular}




\section{Appendix 6. Example of thematic data analysis}

\begin{tabular}{|c|c|c|c|c|}
\hline Family-Whānau Joining in session & ultural Identity Of The Self & Extended Family-whānau & $\begin{array}{c}\text { Absent due geography or } \\
\text { Estranged Family- } \\
\text { Whānau }\end{array}$ & $\begin{array}{l}\text { Music Therapy Space is } \\
\text { like a bridge or enabler }\end{array}$ \\
\hline $\begin{array}{l}\text { Play music instruments together \#8 J and } \\
\text { Parents enjoyed making music } \\
\text { together. "It was relaxing and enjoyable, } \\
\text { so different from usual therapy sessions" } \\
\text { said Mum \&Dad } \\
\text { \#20Bob was in his room with his younger } \\
\text { brother. They were both keen on using the } \\
\text { microphone and amp. } \\
\text { Initially used a recorded song on ipad to } \\
\text { sing to, but then discarded ipad for LIVE } \\
\text { percussion rhythmic session. }\end{array}$ & $\begin{array}{l}\text { Identity, karakia \#35 Husband \& wife } \\
\text { recalled memories of when they played } \\
\text { music together in England, in bands etc. } \\
\text { Their "life was full of music and dance." } \\
\text { \#34 Bob also practised the ukulele } \\
\text { Samoan song from his childhood we } \\
\text { worked on over the past two weeks. He } \\
\text { really works hard at retention of chords } \\
\text { and words, but it is definitely a huge } \\
\text { effort. He enjoyed this cognitive } \\
\text { challenge and his achievement, } \\
\text { especially as we added a second verse } \\
\text { \#12..." I asked if he meant } \\
\text { "Te Reo" to which he nodded } \\
\text { and said "Ai"); but he wished } \\
\text { to listen } \\
\text { and joined in final lyric when } \\
\text { prompted, } \\
\text { speaking the final lyrics. } \\
\text { \#4 S very slowly turned to make } \\
\text { eye-contact, said "Yes" to singing; } \\
\text { and seemed to engage with small } \\
\text { smile as I sang Tongan song... } \\
\text { asking her help in my } \\
\text { pronunciation. }\end{array}$ & $\begin{array}{l}\text { Collaborative } \\
\text { Therapeutic Relationship } \\
\text { \#21MT to build on vocal } \\
\text { volume and cognitive goals } \\
\text { from earlier this week. } \\
\text { \#28Again Sally (Samoan } \\
\text { Cleaning lady who is pro } \\
\text { musician)returned \& was } \\
\text { persuaded to play Samoan \& } \\
\text { Maori Song (she prefers the } \\
\text { latter) - POKAREKARE ANA - } \\
\text { which Bob beat-boxed to! It } \\
\text { was the first time I have ever } \\
\text { heard such a musical thing. } \\
\text { Samoan male staff carer came } \\
\text { in and played the tambourine, } \\
\text { drum to the brothers } \\
\text { musicking. } \\
\text { \#8 Physio invited me along to } \\
\text { Physio session tomorrow - to } \\
\text { dance to Beyonce with Client. } \\
\text { She also shared Serena's } \\
\text { Whānau say she likes the } \\
\text { GREASE musical. }\end{array}$ & $\begin{array}{l}\text { Client misses whānau } \\
\text { \#22with staff \& to sing out "I } \\
\text { wanna go home!" She } \\
\text { managed this at first with a sad } \\
\text { expression\& then when } \\
\text { encouraged by staff who clearly } \\
\text { felt for her, she actually said } \\
\text { "Yeah! I wanna go home!" \& } \\
\text { she laughed. } \\
\text { Client's whānau were very shy } \\
\& \text { cried when Serena started } \\
\text { singing as they said they have } \\
\text { not seen her } \\
\text { sing } \\
\text { "for a long time." } \\
\text { \#12 When asked if Hess would } \\
\text { like a copy of this waiata, } \\
\text { indicated that he would like me } \\
\text { to adhere it to space } \\
\text { underneath the large } \\
\text { photo on the wall of all his } \\
\text { Mokopuna }\end{array}$ & 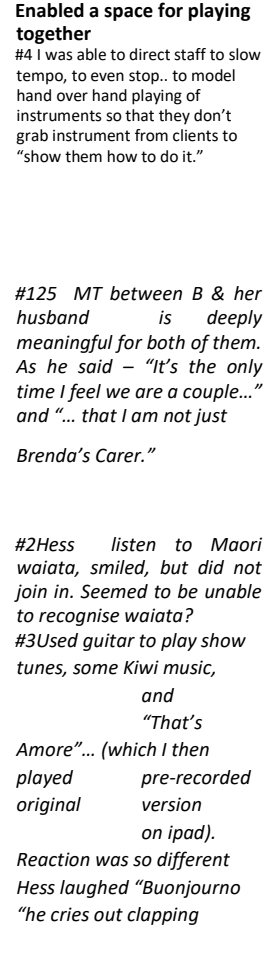 \\
\hline $\begin{array}{l}\text { Sing \& dance together } \\
\text { \#45 less emotional outbursts from ..\& when } \\
\text { she asked ..to help her move her } \\
\text { hemiparetic hand, seemed able to follow } \\
\text { physio advice to encourage her by saying } \\
\text { "YOU take your hand yourself dear, \& count } \\
\text { out the beat." She did so \& continued thru- } \\
\text { out! }\end{array}$ & $\begin{array}{l}\text { Kapa haka } \\
\text { \#138 Humming of familiar kapa } \\
\text { haka music to invite him into } \\
\text { humming. } \\
\text { \#133 Use of guitar or acapella } \\
\text { quietly singing familiar kapa haka } \\
\text { waiata to invite him to remember } \\
\text { \#25 Is sister is visiting from East Cape. J } \\
\text { wants her to learn the ukulele with her. } \\
\text { J's sister does not think she could learn } \\
\text { anything in her short time there, but } \\
\text { gives in to her sister. I seemed so } \\
\text { overjoyed that her sister listened to her. } \\
\text { Asked them to share their sacred } \\
\text { mihimihi } \\
\text { aloud This seemed to provide added } \\
\text { motivation of } \\
\text { Breathing \& vocal exercises work. }\end{array}$ & $\begin{array}{l}\text { Joining in MT } \\
\text { \#11 Live music on ukulele } \\
\text { enroute back to House Lounge } \\
\text { \& in lounge } 30 \text { minutes with } \\
\text { Serena's Whānau, and other } \\
\text { House Clients and Staff who } \\
\text { either sung, or beat a rhythm } \\
\text { on the bongo drums. }\end{array}$ & $\begin{array}{l}\text { Not joining in? } \\
\text { \#34Hess seemed weary and his } \\
\text { Daughter declined to stay, shared } \\
\text { that he was tired, but came back to } \\
\text { door that Hess had said he would like } \\
\text { music therapy. she asked for quick } \\
\text { word, \& shared her stress } \\
\text { \&exhaustion \& worry! }\end{array}$ & $\begin{array}{l}\text { Creative space } \\
\text { \#20 Brenda able to express\& } \\
\text { communicate her anxiety\&grief in } \\
\text { a positive framework } \\
\text { \#135 Brenda seemed to } \\
\text { surprise herself with what she was } \\
\text { able to produce \& create on ipad. } \\
\text { As she said herself, "I created a } \\
\text { ryythm" which husband \&I sung } \\
\text { "In the Jungle" to. She then } \\
\text { confidently created "marimba } \\
\text { beats" as she begun to singspeak } \\
\text { SWAY } \\
\text { \#44 Facilitated some meaningful } \\
\text { time, karakia, music from nephew } \\
\text { as a whāaubetween K \& her } \\
\text { Mum\& sibling, who are unable to } \\
\text { attend a tangi back at their East } \\
\text { Coast hapu. }\end{array}$ \\
\hline $\begin{array}{l}\text { Song composition with } \\
\text { siblings/family-whānau } \\
\text { \# Bob then shared a beautiful song he } \\
\text { wrote for his Daughter. He played piano \& } \\
\text { his sister sent it to him in a loop... on his } \\
\text { tablet. He SUNG the verse \& chorus lyrics } \\
\text { he had written } \\
\text { \#124 Brenda \& Husband both } \\
\text { shared music memories and sang } \\
\text { along. }\end{array}$ & $\begin{array}{l}\text { Waiata to also support } \\
\text { cognitive rehabilitation } \\
\text { \#13 Use of guitar or acapella } \\
\text { quietly singing familiar kapa } \\
\text { haka waiata to invite Bill to } \\
\text { remember } \\
\text { \#14Bill again joined in } \\
\text { Tutirimai Nga lwi (twice sung } \\
\text { through), \& Hallelujah chorus } \\
\text { (which he hummed tunefully). } \\
\text { This also meant he used vowel } \\
\text { sounds to complete phrasing of } \\
\text { this waiata. } \\
\text { I overhear SLT say that perhaps K } \\
\text { doesn't feel } \\
\text { confidence in her voice due to } \\
\text { Retts's beautiful voice... }\end{array}$ & $\begin{array}{l}\text { Client seen in a new } \\
\text { light by } \\
\text { staff } \\
\text { \#8Therapeutic } \\
\text { relationships enabled } \\
\text { Client to share new } \\
\text { information about her } \\
\text { professional } \\
\text { background \& } \text { musical } \\
\text { staff.. surprised } \\
\text { \#121-123 Husband says proud } \\
\text { of Brenda's ability to "have } \\
\text { beautiful nails all her life } \\
\text { despite her hard work keeping } \\
\text { home, garden \& with } \\
\text { employment." He also } \\
\text { mentioned that she was a } \\
\text { pantyhose model of the } 60 \text { s } 70 s \\
\text { \& shared that she dated Cliff } \\
\text { Richards, "but she chose ME!" }\end{array}$ & $\begin{array}{l}\text { Whānau want to } \\
\text { witness clients MT } \\
\text { \#118 husband was very moved } \\
\text { when he watched video of his } \\
\text { wife speaking \& kept } \\
\text { commenting "...see, Brenda } \\
\text { does have emotional } \\
\text { awareness of others - she's } \\
\text { lovely."\#77Janey has new } \\
\text { goals: to strengthen Kapa Haka } \\
\text { skills says OT \& SLT. Today } \\
\text { Janey worked hard on breath } \\
\text { support \& vocal technique } \\
\text { exercises. I ask her stepmum } \\
\text { to please join in so that they } \\
\text { could work on these exercises } \\
\text { together. Mum seemed happy } \\
\text { with Janey's vocal strength } \\
\text { development. }\end{array}$ & $\begin{array}{l}\text { Co-creators of music } \\
\qquad \text { with } \\
\text { whānau } \\
\text { \#38-\#41 janey was in the kitchen } \\
\text { eating afternoon tea } \\
\text { of fruit with her older sister and } \\
\text { stepmum...mum said she was in a } \\
\text { quandary but had more or less } \\
\text { decided not to go back home for } \\
\text { the tangi of her nephew. } \\
\text { Stepmum asks to play the guitar. }\end{array}$ \\
\hline
\end{tabular}


Appendix 7. Example of groupings of themes after thematic data analysis

\begin{tabular}{|c|c|c|}
\hline CODING & THEME? & THEME? \\
\hline $\begin{array}{l}\text { Interdisciplinary team } \\
\text { Reminiscing with } \\
\text { spouse }\end{array}$ & $\begin{array}{l}\text { Collaborative } \\
\text { relationship } \\
\text { Spousal relationship }\end{array}$ & $\begin{array}{l}\text { Staff as family-whānau Relationship } \\
\text { with spouse }\end{array}$ \\
\hline $\begin{array}{l}\text { Personal sharing } \\
\text { Therapeutic } \\
\text { relationship } \\
\text { Therapeutic } \\
\text { relationship }\end{array}$ & $\begin{array}{l}\text { Collaborative } \\
\text { Therapeutic } \\
\text { relationship } \\
\text { Collaborative } \\
\text { relationship }\end{array}$ & \begin{tabular}{|cc}
\multicolumn{3}{c}{ Collaborative } \\
Extended $\quad$ Whānau & team \\
Interpersonal relationship &
\end{tabular} \\
\hline $\begin{array}{l}\text { Family goal is MT } \\
\text { session } \\
\text { Family plan music space } \\
\text { Family control of music } \\
\text { space }\end{array}$ & $\begin{array}{l}\text { Family in session } \\
\text { Proactive, collaborative } \\
\text { Shared music \& Cultural } \\
\text { Identity }\end{array}$ & $\begin{array}{l}\text { Family in session } \\
\text { Enables client Surprises } \\
\text { Teams Feeling of } \\
\text { pride/Empowerment }\end{array}$ \\
\hline $\begin{array}{l}\text { Family donate music } \\
\text { instrumt. Family } \\
\text { gift mealofa to } \\
\text { facility } \\
\text { Family agency }\end{array}$ & $\begin{array}{l}\text { Family gathering/share } \\
\text { music } \\
\text { Family reminisce } \\
\text { together } \\
\text { Family } \\
\text { remember happier days }\end{array}$ & $\begin{array}{l}\text { Cultural context importance } \\
\text { Cultural identity of client vs Kiwi } \\
\text { Palagi client problems }\end{array}$ \\
\hline $\begin{array}{l}\text { Missing husband } \\
\text { expressed Client } \\
\text { expresses inner } \\
\text { emotion } \\
\text { Communicate inner } \\
\text { emotion }\end{array}$ & $\begin{array}{l}\text { Shared video of client to } \\
\text { spouse Family in session } \\
\text { Husband } \\
\text { moved by wife's } \\
\text { music }\end{array}$ & $\begin{array}{l}\text { Surprise view of client by } \\
\text { ppouse }\end{array}$ \\
\hline $\begin{array}{l}\text { Challenges around } \\
\text { boundaries } \\
\text { Complexities of } \\
\text { boundaries } \\
\text { Complex Boundaries }\end{array}$ & $\begin{array}{l}\text { Breakdown of staff } \\
\text { relations } \\
\text { Trusting relationships } \\
\text { vital } \\
\text { Importance of trust }\end{array}$ & $\begin{array}{l}\text {-yric } \\
\text { Client verbalises love for } \\
\text { spouse } \\
\text { Confidence grows in music }\end{array}$ \\
\hline $\begin{array}{l}\text { Staff relationship } \\
\text { breaks down Client } \\
\text { verbalises suspicion } \\
\text { of carers } \\
\text { Client verbalised re } \\
\text { stolen items }\end{array}$ & $\begin{array}{l}\text { Complexities in staff } \\
\text { relationships } \\
\text { Trusting relationship is crucial to health }\end{array}$ & $\begin{array}{l}\text { Trusting relationship \& mental } \\
\text { health links }\end{array}$ \\
\hline $\begin{array}{l}\text { Student advocacy for } \\
\text { client Complex } \\
\text { student/staff } \\
\text { relationships } \\
\text { Concern with lable } \\
\text { put on client }\end{array}$ & $\begin{array}{l}\text { Contacted Spouse } \\
\text { Actively seeking family } \\
\text { presence Pro- } \\
\text { active student practice }\end{array}$ & $\begin{array}{l}\text { Family in session } \\
\text { trusting } \\
\text { relationship } \\
\text { Family in session is key }\end{array}$ \\
\hline $\begin{array}{l}\text { Video footage of } \\
\text { client } \\
\text { Spouse overcome } \\
\text { with emotion } \\
\text { Spouse organises } \\
\text { family session }\end{array}$ & $\begin{array}{l}\text { Need for spouse/whānau } \\
\text { to } \\
\text { 'see' progress }\end{array}$ & $\begin{array}{l}\text { Spouse feels hope \& shares news } \\
\text { Spouse empowered to believe } \\
\text { Spouse feels 'married' again }\end{array}$ \\
\hline
\end{tabular}


Appendix 8. Table (a) and (b)

Example of Self-esteem support, in the face of domestic violence

\begin{tabular}{|c|c|c|c|}
\hline Data & $\begin{array}{l}\text { What is happening } \\
\text { Code }\end{array}$ & $\begin{array}{c}\text { How is this } \\
\text { experience } \\
\text { enhancing client } \\
\text { wellbeing }\end{array}$ & $\begin{array}{c}\text { What I am } \\
\text { thinking } \\
\text { therapeutically }\end{array}$ \\
\hline $\begin{array}{l}\# \mathbf{2 1} \text { *Serena was in her chair reclining } \\
\text { in Lounge with another client and } \\
\text { two Staff. She again chose the purple } \\
\text { egg shaker with handle - only this } \\
\text { time she said "the shaker." Was } \\
\text { awake half the time, yet even when } \\
\text { her eyes were closed, quietly sung } \\
\text { the whole } \times 3 \text { verses and chorus of "In } \\
\text { The Jungle" - complete with melodic } \\
\text { vocal parts. }\end{array}$ & $\begin{array}{l}\text { Staff \& } \\
\text { client in } \\
\text { session } \\
\text { Client r makes } \\
\text { cognitive decision, } \\
\text { verbalises } \quad \& \\
\text { physically chooses a } \\
\text { music instrument }\end{array}$ & $\begin{array}{l}\text { Other clients, } \\
\text { staff in session. } \\
\text { Client \& Staff } \\
\text { have a music } \\
\text { making } \\
\text { experience } \\
\text { Client smiles and } \\
\text { laughs aloud - } 1^{\text {st }} \\
\text { time } \\
\text { Client surprises } \\
\text { all with 'singing' } \\
\text { whole song. }\end{array}$ & $\begin{array}{l}\text { Is the client more motivated } \\
\text { due to the presence of staff } \\
\text { whom she has already built } \\
\text { up a relationship with? } \\
\text { Or is music in a } \\
\text { group by its } \\
\text { nature } \\
\text { motivating } \\
\text { anyway? } \\
\text { Detection of } \\
\text { sweating by } \\
\text { client - physical } \\
\text { exertion? }\end{array}$ \\
\hline
\end{tabular}

\section{Example of Care staff collaborate as "Institutional Whānau" of client}

\begin{tabular}{|c|c|c|c|}
\hline $\begin{array}{c}\text { Code Connection } \\
\text { to lyric }\end{array}$ & What is happening & $\begin{array}{l}\text { How is this } \\
\text { experience } \\
\text { demonstrating } \\
\text { FWCMTA }\end{array}$ & $\begin{array}{l}\text { What I am } \\
\text { thinking } \\
\text { therapeutically }\end{array}$ \\
\hline $\begin{array}{l}\text { Client sings all verses \& } \\
\text { chorus as well as the } \\
\text { melodic vocalisations }\end{array}$ & $\begin{array}{l}\text { Client's cognitive function } \\
\text { surprises staff and spurs } \\
\text { them to join in and play } \\
\text { music instruments \& sing }\end{array}$ & $\begin{array}{l}\text { Staff perception of client } \\
\text { changes } \\
\text { Client has positive perception } \\
\text { of herself \& of staff through } \\
\text { their musicking } \\
\text { Interpersonal } \\
\text { relationships } \\
\text { supported } \\
\text { Collaborative } \\
\text { music making }\end{array}$ & $\begin{array}{l}\text { Staff collaboration seems to } \\
\text { enhance client wellbeing ..also } \\
\text { supporting the staff \& client } \\
\text { relationship. } \\
\text { Client sweating is } \\
\text { it only due to } \\
\text { physical exertion? } \\
\text { Need to } \\
\text { observe closely }\end{array}$ \\
\hline
\end{tabular}




\section{Appendix 9 Last Word}

Archives example of my exploration of data mining summary: dated "December 2015" but in shifting house, twice in four months it was lost. Finding this 2017 the night before I finish, is like an angel saying, "Hey, you were good enough back then... so keep going forward with a drumroll \& a song in your heart..."

\section{Overview of family/whānau-centred music therapy data?}

- When examining my clinical data collected over a period of three to eight months, I found that the Staff throughout the facility - from the care workers, cleaners, medical, psychological, therapist, to the managing directors - actively seek to foster an environment of inclusion during client and their family/whānau's rehabilitation experience. This was facilitated through weekly meetings with client and family/whānau. The data also highlighted how music therapy supported this because of its elements of "inclusiveness" during the musicking experience between client, family/whānau, and staff which was facilitated by the student music therapist.

- Initial analysis of the music therapy (MT) clinical data, show that whenever possible, the client's personal goals, as well as their family/whānau goals formed the short term objectives and long term goals of MT sessions. These would be added to from the collaborative multi-disciplinary team discussions, and the observation, assessment MT visits. This was common practice within the rehabilitation centre.

- Further examination of the clinical data shows how music therapy can support families/whānau through their participation in the sessions, singing with their loved one, playing instruments together, or in support of each other's musicking. An example of this would be a parent playing the guitar for their child who was a client, or vice versa.

- The data supports the existing knowledge of how music therapy can provide families/whānau with positive interactive musicking experiences. It also illustrated how client \& whānau could become overwhelmed with feelings of relief at the possibility of emotional or physiological recovery for themselves or their loved one: "I feel like a married couple again, and not just a carer," "My daughter can sing and play an instrument again," or "It felt so good to be a family again"...

- Analysis of clients' data showed how feelings of agency, restoration when MT allows them to return to their pre-injury role of parent, spouse, offspring, siblings, or grandparent and mokopuna. Or close family/whānau friend.

- Of particular interest for me as a Polynesian person, were the collaborative cultural music and dance opportunities together with clients and the centre's staff who identified themselves as of Maori, Tongan, Filipino, Indian, Sri Lankan, Fijian and Samoan descent. Inherent within their "ethnic psyche" is the natural-law of Family/Whānau which supercedes that of Individualism. The data showed examples of this in the music making between staff and clients.

- It was also interesting to note within the data the examples of complexities and difficulties around the multi-disciplinary and collaborative model. It is a proven holistic model with the client's wellbeing and rehabilitation at the forefront, but it also comes fraught with complications due to misunderstandings between team members. The data seemed to highlight that this is probably part and parcel of any organisation using the collaborative model, but that the positive outcomes for both client and family/whānau far outweighs any negatives. 